\title{
New Data for Aerosols Generated by Releases of Pressurized Powders and Solutions in Static Air
}

Manuscript Completed: April 1987

Date Published: May 1987

Prepared by

M. Y. Ballinger, S. L. Sutter, W. H. Hodgson

Pacific Northwest Laboratory

Richland, WA 99352

\section{Prepared for}

Division of Fuel Cycle, Medical, Academic and Commercial Use Safety

Office of Nuclear Material Safety and Safeguards

U.S. Nuclear Regulatory Commission

Washington, DC 20555

NRC FIN B2481-5

\section{DISCLAIMER}

This report was prepared as an account of work sponsored by an agency of the United States Government. Neither the United States Government nor any agency thereof, nor any of their employees, makes any warranty, express or implied, or assumes any legal liability or responsibility for the accuracy, completeness, or usefulness of any information, apparatus, product, or process disclosed, or represents that its use would not infringe privately owned rights. Reference herein to any specific commercial product, process, or service by trade name, trademark, manufacturer, or otherwise does not necessarily constitute or imply its endorsement, recommendation, or favoring by the United States Government or any agency thereof. The views and opinions of authors expressed herein do not necessarily state or reflect those of the United States Government or any agency thereof.

This document is

PUBLICLY RELEASABLE

$\frac{3 \text { any steele }}{\text { Authorizing Otticial }}$
Date: $8-24-0 A$




\section{DISCLAIMER}

This report was prepared as an account of work sponsored by an agency of the United States Government. Neither the United States Government nor any agency Thereof, nor any of their employees, makes any warranty, express or implied, or assumes any legal liability or responsibility for the accuracy, completeness, or usefulness of any information, apparatus, product, or process disclosed, or represents that its use would not infringe privately owned rights. Reference herein to any specific commercial product, process, or service by trade name, trademark, manufacturer, or otherwise does not necessarily constitute or imply its endorsement, recommendation, or favoring by the United States Government or any agency thereof. The views and opinions of authors expressed herein do not necessarily state or reflect those of the United States Government or any agency thereof. 


\section{DISCLAIMER}

Portions of this document may be illegible in electronic image products. Images are produced from the best available original document. 


\section{NOTICE}

This report was prepared as an account of work sponsored by an agency of the United States Government. Neither the United States Government nor any agency thereof, or any of their employees. makes any warranty, expressed or implied, or assumes any legal liability of re. sponsibility for any third party's use, or the results of such use, of any information, apparatus. product or process disclosed in this report, or represents that its use by such third party would not infringe privately owned rights.

\section{NOTICE}

\section{Availability of Reference Materials Cited in NRC Publications}

Most documents cited in NRC publications will be available from one of the following sources:

1. The NRC Public Document Room, 1717 H Street, N.W. Washington, DC 20555

2. The Superintendent of Documents, U.S. Government Printing Office, Pust Office Box 37082. Washington, DC 20013.7082

3. The National Technical Information Service, Springfield, VA 22161

Although the listing that follows represents the majority of documents cited in NRC publications. it is not intended to be exhaustive.

Referenced documents available for inspection and copying for a fee from the NRC Public Docu. ment Room include NRC correspondence and internal NRC memoranda; NRC Office of Inspection and Enforcement bulletins, circulars, information notices, inspection and investigation notices; Licensee Event Reports; vendor reports and correspondence; Commission papers; and applicant and licensee documents and correspondence.

The following documents in the NUREG series are available for purchase from the GPO Sales Program: formal NRC staff and contractor reports, NRC-sponsored conference proceedings, and NRC booklets and brochures. Also available are Regulatory Guides, NRC regulations in the Code of Federal Regulations, and Nuclear Regulatory Commission /ssuances.

Documents available from the National Technical Information Service include NUREG series reports and technical reports prepared by other federal agencies and reports prepared by the Atomic Energy Commission, forerunner agency to the Nuclear Regulatory Commission.

Documents 'available from public and special technical libraries include all open literature items, such as books, journal and periodical articles, and transactions. Federal Register notices, federal and state legislation, and congressional reports can usually be obtained from these libraries.

Documents such as theses, dissertations, foreign reports and transiations, and non.NRC conference proceedings are available for purchase from the organization sponsoring the publication cited.

Single copies of NRC draft reports are available free, to the extent of supply, upon written request to the Division of Technical Information and Document Control. U.S. Nuclear Regulatory Com. mission, Washington, DC 20555.

Copies of industry codes and standards used in a substantive manner in the NRC regulatory process are maintained at the NRC Library, 7920 Norfolk Avenue, Bethesda, Maryland, and are available there for reference use by the public. Codes and standards are usually copyrighted and may be purchased from the originating organization or, if they are American National Standards, from the American National Standards Institute, 1430 Broadway, New York, NY 10018. 


\section{EXECUTIVE SUMMARY}

Pacific Northwest Laboratory conducted three sets of experiments to measure aerosols generated by pressurized releases. These aerosols are generated from releases of uranine pressurized with carbon dioxide, flashing sprays, and low-pressure depleted uranium dioxide powder releases. The purpose of these experiments was to supplement data from earlier experiments investigating the source term from pressurized releases. These experiments are part of a program to develop source-term estimation methods for analysis of accidents in nuclear fuel cycle facilities.

Mass airborne and particle size distribution of aerosols generated by $\mathrm{CO}_{2}$ /uranine releases, flashing sprays of uranine, and low-pressure depleted uranium powder releases were measured. Source volume and release pressure varied in each set of experiments. Source volumes were 100 and $350 \mathrm{~mL}$ for $\mathrm{CO}_{2} /$ uranine releases and flashing sprays and 100 and $350 \mathrm{~g}$ for low-pressure powder releases. Release pressure varied from 9 to 500 psig.

The mass airborne from $\mathrm{CO}_{2}$-pressurized releases was larger than those from comparable air-pressurized systems. However, the differences in mass airborne from $\mathrm{CO}_{2}$ - and air-pressurized systems was not as great as anticipated, based on the amount of gas dissolved in the liquid and the volume of liquid ejected from the pressurized-airborne release equipment (PARE) for both systems.

Flashing sprays produced a much larger source term than all other pressurized releases performed under this program. All but one of the flashingspray releases resulted in all of the liquid being evaporated or ejected from the PARE.

Low-pressure powder releases provided data in the energy region between previously reported spilis and pressurized releases. Mass airborne increased with solution volume and release pressure as expected. 
CONTENTS

EXECUTIVE SUMMARY $\ldots \ldots \ldots \ldots \ldots \ldots \ldots \ldots \ldots \ldots \ldots \ldots \ldots \ldots \ldots \ldots \ldots \ldots, \ldots \ldots \ldots$

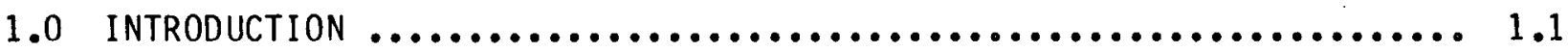

2.0 EXPERIMENTAL PROCEDURES $\ldots \ldots \ldots \ldots \ldots \ldots \ldots \ldots \ldots \ldots \ldots \ldots \ldots \ldots \ldots \ldots \ldots \ldots \ldots \ldots \ldots$

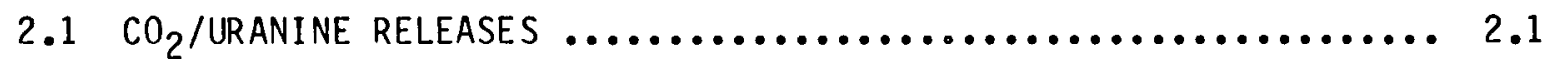

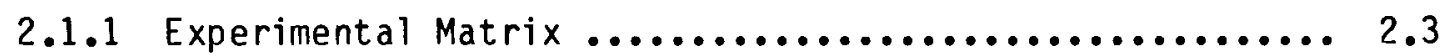

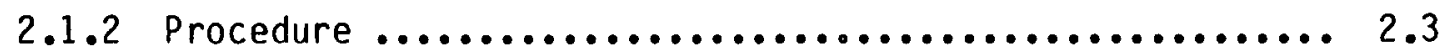

2.1.3 Sample Analysis $\ldots \ldots \ldots \ldots \ldots \ldots \ldots \ldots \ldots \ldots \ldots \ldots \ldots . . . \ldots \ldots$

2.2 FLASHING-SPRAY RELEASES $\ldots \ldots \ldots \ldots \ldots \ldots \ldots \ldots \ldots \ldots \ldots \ldots \ldots \ldots \ldots \ldots$

2.3 LOW-PRESSURE POWDER RELEASES $\ldots \ldots \ldots \ldots \ldots \ldots \ldots \ldots \ldots \ldots \ldots \ldots \ldots$

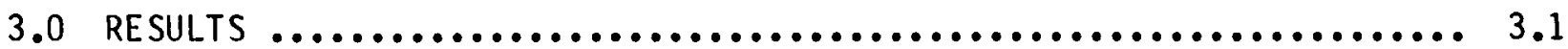

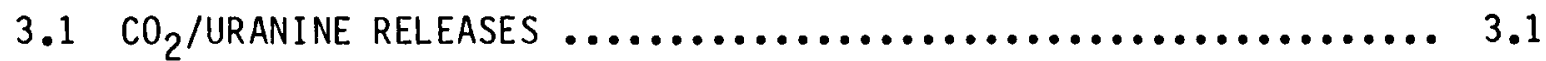

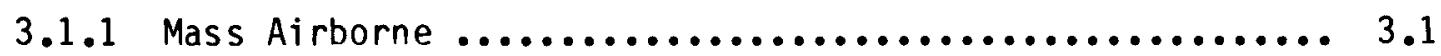

3.1.2 High-Speed Photography and Liquid Ejected ............ 3.3

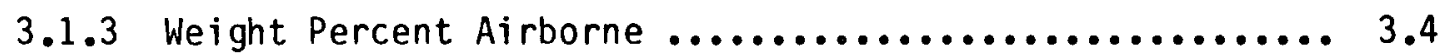

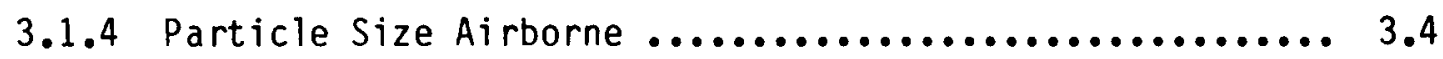

3.2 FLASHING-SPRAY RELEASES $\ldots \ldots \ldots \ldots \ldots \ldots \ldots \ldots \ldots \ldots \ldots \ldots \ldots \ldots \ldots$

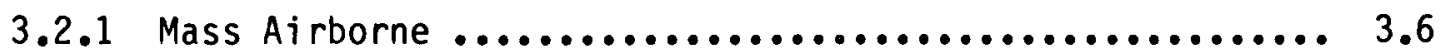

3.2.2 Liquid Ejection ............................. 3.7

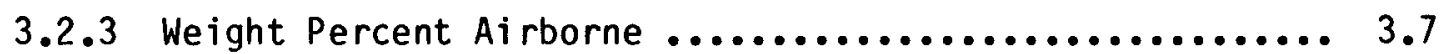

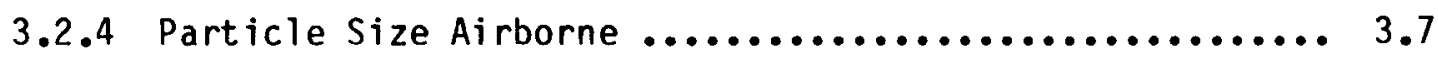

3.3 LOW-PRESSURE DUO RELEASES $\ldots \ldots \ldots \ldots \ldots \ldots \ldots \ldots \ldots \ldots \ldots \ldots \ldots$

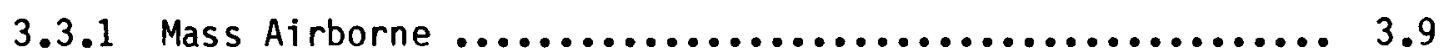

3.3.2 Weight Percent Airborne $\ldots \ldots \ldots \ldots \ldots \ldots \ldots \ldots \ldots \ldots \ldots . . \ldots \ldots$

3.3.3 Particle Size Distribution and Powder Ejected ......... 3.10 
4.0 REFERENCES $\ldots \ldots \ldots \ldots \ldots \ldots \ldots \ldots \ldots \ldots \ldots \ldots \ldots \ldots \ldots \ldots \ldots \ldots \ldots \ldots \ldots \ldots \ldots \ldots \ldots . \ldots . \ldots$ APPENDIX A - EXPERIMENTAL DATA $\ldots \ldots \ldots \ldots \ldots \ldots \ldots \ldots \ldots \ldots \ldots \ldots \ldots \ldots \ldots \ldots \ldots$ APPENDIX B - CALCULATIONS ................................... B... 
FIGURES

2.1 PARE Modification for $\mathrm{CO}_{2}$ /Uranine Release Experiments ........... 2.1

2.2 Sampling for a Pressurized Release with High-Volume Samplers ..... 2.3

2.3 PARE Modifications for Flashing-Spray Release Experiments ....... 2.5

2.4 Measured and Predicted Temperatures for Flashing-Spray Releases ... 2.6

2.5 PARE Modification for Low-Pressure Powder Releases ............. 2.7

3.1 Weight Percent Airborne as a Function of Mole Fraction of Pressurizing Gas ..................................... 3.2

3.2 Solution Volumes Ejected from PARE in Air- and $\mathrm{CO}_{2}$ Pressurized Releases ................................... 3.5

3.3 Weight Percent of Uranine Airborne in Liquid-Pressurized Releases ........................................... 3.8

3.4 Weight Percent DUD Airborne Versus Pressure ................. 3.12

B.1 Plot of $1 / \mathrm{H}$ Versus Temperature for $\mathrm{CO}_{2}$ Solubility in $\mathrm{H}_{2} \mathrm{O}$ at 1 Atmosphere ......................................... B.2

B.2 $1 / \mathrm{H}$ Versus Partial Pressure of $\mathrm{CO}_{2}$ for Temperature Range of Experiments $\ldots \ldots \ldots \ldots \ldots \ldots \ldots \ldots \ldots \ldots \ldots \ldots \ldots \ldots \ldots \ldots \ldots \ldots \ldots \ldots \ldots \ldots \ldots . . \ldots . \ldots$

B.3 Mole Fraction of $\mathrm{CO}_{2}$ Dissolved in Uranine Solutions Versus Temperature at Partial Pressure Indicated .................... B.6

B.4 Plot of Henry's Constant, $H$, Versus Partial Pressure of Oxygen and Nitrogen ............................................

\section{TABLES}

2.1 Estimated Mole Fraction of Test Gases Dissolved in Uranine Solution

3.1 Uranine Mass Airborne from Air- and $\mathrm{CO}_{2}-$ Pressurized Releases 
3.3 Weight Percent Airborne from Air- and $\mathrm{CO}_{2}-\mathrm{Pressurized}$

Releases .......................................... 3.5

3.4 Median AED of Particles Generated by Air- and $\mathrm{CO}_{2}$-Pressurized

Liquid Releases ...................................... 3.6

3.5 Mass of Uranine Made Airborne by Flashing Sprays of

Superheated Liquid

3.6 Weight Percent Uranine Airborne from Flashing-Spray

Releases

3.7 Median AED of Particles Generated by Flashing-Spray

Releases

3.8 Average DU0 Mass Airborne from Pressurized Powder

Releases

3.9 Average Weight Percent Airborne from Pressurized

DuO Releases

3.10 Average Median AED of Particles Generated by

Pressurized-Powder Releases, $\mu \mathrm{m}$

A.1 Mass Airborne from $\mathrm{CO}_{2}$-Pressurized Releases

of Uranine Solutions...................................

A.1

A.2 Median AED of Particles Produced by $\mathrm{CO}_{2}$-Pressurized Releases

of Uranine Solutions.................................... A.1

A.3 Mass Airborne from Flashing-Spray Releases of Superheated

Liquids

A.4 Median AED of Particles Produced by Flashing-Spray Releases of Superheated Uranine Solutions.

A.5 Mass Airborne from Low-Pressure DuO Releases.................. A.3

A.6 Median AED of Particles Produced by Low-Pressure DUO Releases...... A.3

B.1 Mole Fraction and $1 / \mathrm{H}$ by Temperature and Pressure ..................

B.2 Mole Fraction of $\mathrm{CO}_{2}$ at Experimental Pressures .................. B.5

B.3 Mole Fraction of $\mathrm{CO}_{2}$ Dissolved in Uranine for $\mathrm{CO}_{2}$-Pressurized Releases.

B.4 Mole Fraction of Air Dissolved in Uranine of Air-Pressurized

Releases 


\subsection{INTRODUCTION}

Aerosol generation characteristics of accidental particle releases in nuclear fuel cycle facilities are being investigated at Pacific Northwest Laboratory (PNL). The work is sponsored by the U.S. Nuclear Regulatory Commission, Office of Nuclear Materials Safety and Safeguards. Safety analysis reports and environmental impact statements must evaluate the consequence of postulated accidents in or involving the facility in question. During an accidental release from a nuclear fuel cycle facility, the dominant pathway to man is usually through airborne particles, so it is necessary to determine an aerosol source term (i.e., the quantity of material initially airborne from an accident).

Earlier work (Sutter et a1. 1981; Sutter 1983) reported on free-fall spills and pressurized releases of powders and liquids in static air. This report covers results of additional pressurized-release experiments conducted as part of an ongoing study of accident-generated aerosols. These experiments dealt with pressurized releases of liquid using a soluble gas, flashing sprays, and pressurized releases in the energy region between previously reported spills and pressurized releases.

Sutter reported that liquid releases from the pressurized-airborne release equipment (PARE), using air as a pressurizing gas, were lower than anticipated. High-speed photography revealed that the release seemed to be a possible atomization of the liquid caused by the rapid depressurization. The only noticeable release was a rapidly moving cloud, and almost all the solution volumes remained in the PARE. These findings lead to speculation that the mass airborne may be a function of the amount of gas dissolved in solutions.

To test this theory, carbon dioxide, a highly soluble gas, was used to pressurize contained volumes of sodium fluorescein (uranine) solutions. The gas was injected through openings in a ring below the liquid surface to ensure mixing. Two solution volumes were released at three pressures: 50,250 , and 500 psig. These are the same parameters used in earlier experimental work, thus, allowing us to compare results. Airborne samples were collected for a half-hour following the event with high-volume impactors and a cascade impactor.

Flashing sprays provided data on the source term from rapid releases of hot liquids. This kind of release could result in a much higher source term than other pressurized releases. Three uranine solution volumes of 100,350 , and $700 \mathrm{~cm}^{3}$ were heated using a heat tape on the outside of the PARE. Releases occurred when the vapor pressure of the liquid reached 57, 124, and 240 psig. Airborne samples were collected with $\mathrm{CO}_{2}$-pressurized releases. 
Previous experiments provided source term data in the low-energy region (spills where energy is caused by gravity) and in the high-energy region (pressurized releases at 50 psig or greater where the energy is caused by elevating the gas pressure). Low-pressure releases of depleted uranium dioxide (DU0) powder were performed to investigate releases in the energy region between the two extremes. Source quantities of 100 and $350 \mathrm{~g}$ Duo were used for easier comparison with previous work. Releases were made at 9, 17.5 , and 24.5 psig, and airborne samples were collected as with $\mathrm{CO}_{2}$-pressurized releases and flashing sprays.

Experimental procedures are detailed in Chapter 2, followed by a discussion of the results in Chapter 3. Earlier work (Sutter et al. 1981) described pressurized release experiments performed at PNL. The same release vessel, source materials, pressure chamber (with modifications for flashing sprays and $\mathrm{CO}_{2}$ pressurized releases), sampling procedures, and sample analysis techniques used in these previous experiments were used here.

Airborne mass measurements and median aerodynamic equivalent diameters (AED) are listed in Appendix A. Calculation of solubilities of gases in uranine solutions supporting the experiments using $\mathrm{CO}_{2}$ releases are given in Appendix B. Data from these experiments will be used in ongoing work to develop release models based on physical parameters. 


\subsection{EXPERIMENTAL PROCEDURES}

Experiments were performed to determine the amount of airborne material and the aerodynamic particle size of the aerosols generated by three types of releases: 1) pressurized release of a liquid from a chamber pressurized with carbon dioxide gas, 2) flashing sprays of superheated liquids, and 3) lowpressure release of powdered DU0. These releases took place in static air. Total release from the event was measured; the time-dependent behavior of the aerosol was not investigated. The aerosols were contained in a stainless steel vessel approximately $3-\mathrm{m}$ high and $2.9 \mathrm{~m}$ in dia with a $20-\mathrm{m}^{3}$ volume, about the size of a small room. This vessel is the radioactive aerosol release tank (RART).

\section{$2.1 \mathrm{CO}_{2}$ /URANINE RELEASES}

The PARE used in earlier work was modified for use with $\mathrm{CO}_{2}$, as shown in Figure 2.1. This modification made it possible to fill the entire chamber with

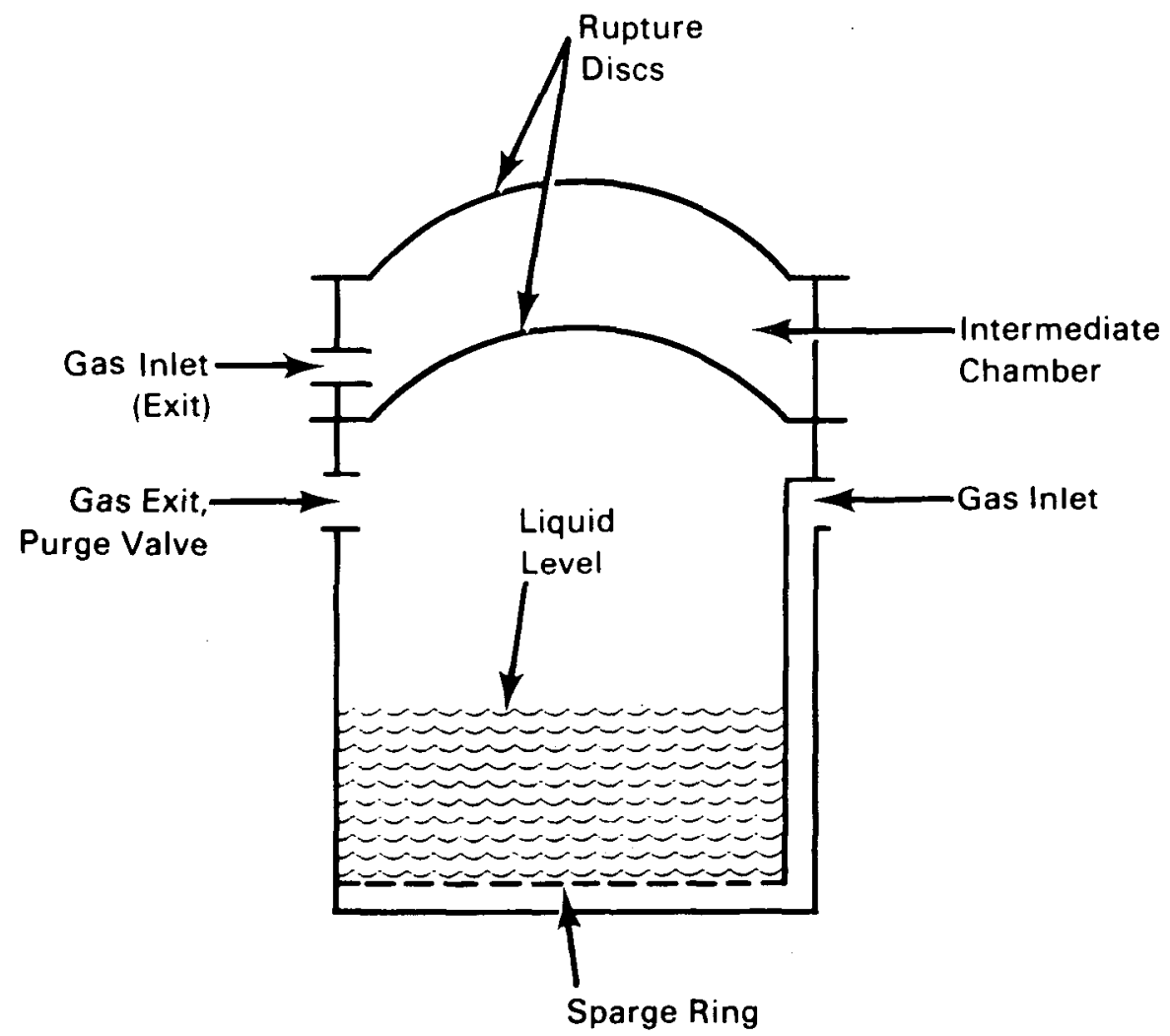

FIGURE 2.1. PARE Modification for $\mathrm{CO}_{2} /$ Uranine Release Experiments 
the pressurizing gas and saturate the contained liquid before the release. The gas enters the pressure chamber through 1/4-in. stainless steel tubing formed into a ring at the bottom of the chamber. To allow intimate mixing of the entering gas and the contained liquid, 42 openings, 1/16 in. dia, were drilled in the ring. The lower chamber was filled with $\mathrm{CO}_{2}$ gas, and air was displaced before the liquid was ejected. This chamber was equipped with a purge valve to accomplish the air displacement. After eliminating air from the PARE, the purge valve was closed and the chambers incrementally pressurized to the preselected experimental level at which the disks were ruptured.

Carbon dioxide was selected as the pressurizing gas because it is highly soluble in aqueous solutions. About 8 to 10 chamber volumes of the gas were run through the PARE before pressurization. The mole fraction of $\mathrm{CO}_{2}$ dissolved in the uranine solution was calculated using Henry's Law with corrections for pressure. The calculations are shown in Appendix B. Values for air were also calculated to enable comparisons with earlier work.

Results of the calculations for both the air-and $\mathrm{CO}_{2}$-pressurizing systems are listed in Table 2.1 and show that 50 times more $\mathrm{CO}_{2}$ than air is potentially dissolved in the solutions. Deviations from the calculated values can result from chemical reactions of the gas with the solutes in the liquid. The $\mathrm{CO}_{2}$ solubility could be affected in an unknown way by the nonvolatile solute uranine.

TABLE 2.1. Estimated Mole Fractipn of Test Gases Dissolved in Uranine Solution $(a)$

\begin{tabular}{|c|c|c|}
\hline $\begin{array}{c}\text { Pressure, } \\
\text { psig } \\
\end{array}$ & $\begin{array}{l}\text { Test } \\
\text { Gas } \\
\end{array}$ & $\begin{array}{c}\text { Mole Fraction } \\
\text { Dissolved }\end{array}$ \\
\hline 500 & Air & $4.2 \times 10^{-4(b)}$ \\
\hline 250 & $\begin{array}{l}\mathrm{CO}_{2} \\
\mathrm{Ai}^{\mathrm{r}}\end{array}$ & $\begin{array}{l}2.0 \times 10^{-2} \\
2.3 \times 10^{-4}\end{array}$ \\
\hline & $\mathrm{CO}_{2}$ & $1.3 \times 10^{-2}$ \\
\hline 50 & $\begin{array}{l}\mathrm{Air}^{2} \mathrm{r} \\
\mathrm{CO}_{2}\end{array}$ & $\begin{array}{l}4.8 \times 10^{-5} \\
2.5 \times 10^{-3}\end{array}$ \\
\hline
\end{tabular}

(a) Assume solubility of gases the same as in water.

(b) Air value calculated assuming 78\%

$\mathrm{N}_{2}, 21 \% 0_{2}$; inert remainder not included. 


\subsubsection{Experimental Matrix}

Uranine solutions with a concentration of $10 \mathrm{~g} / \mathrm{L}$ were used for these experiments. Two volumes $(100$ and $350 \mathrm{cc})$ and three pressures $(50,250$, and $500 \mathrm{psig}$ ) were used to enable direct comparison of the results with earlier work (Sutter 1983). Experimental pressures were monitored with a transducer indicator that was calibrated before use to an accuracy of plus or minus $0.5 \%$. The chamber pressure was displayed as a digital readout.

\subsubsection{Procedure}

The general sampling and experimental procedure used in conducting the experiments is shown in Figure 2.2. First, both chambers were pressurized, then the rupture discs were broken by depressurizing the intermediate chamber, and the liquid was ejected. Samplers were immediately turned on and the particle-laden air pulled onto filters, as indicated by the solid arrows in Figure 2.2. Clean air entered from the rear, as indicated by the 1 ight arrows. These experiments were conducted in the RART.

High-volume samplers equipped with glass fiber filters were used for mass sampling; a cascade impactor was used for size distribution samples. These samplers were located at the same levels as in previous experiments [i.e., high-volume samplers were at the 1 - and 2-m level, and the cascade impactor was

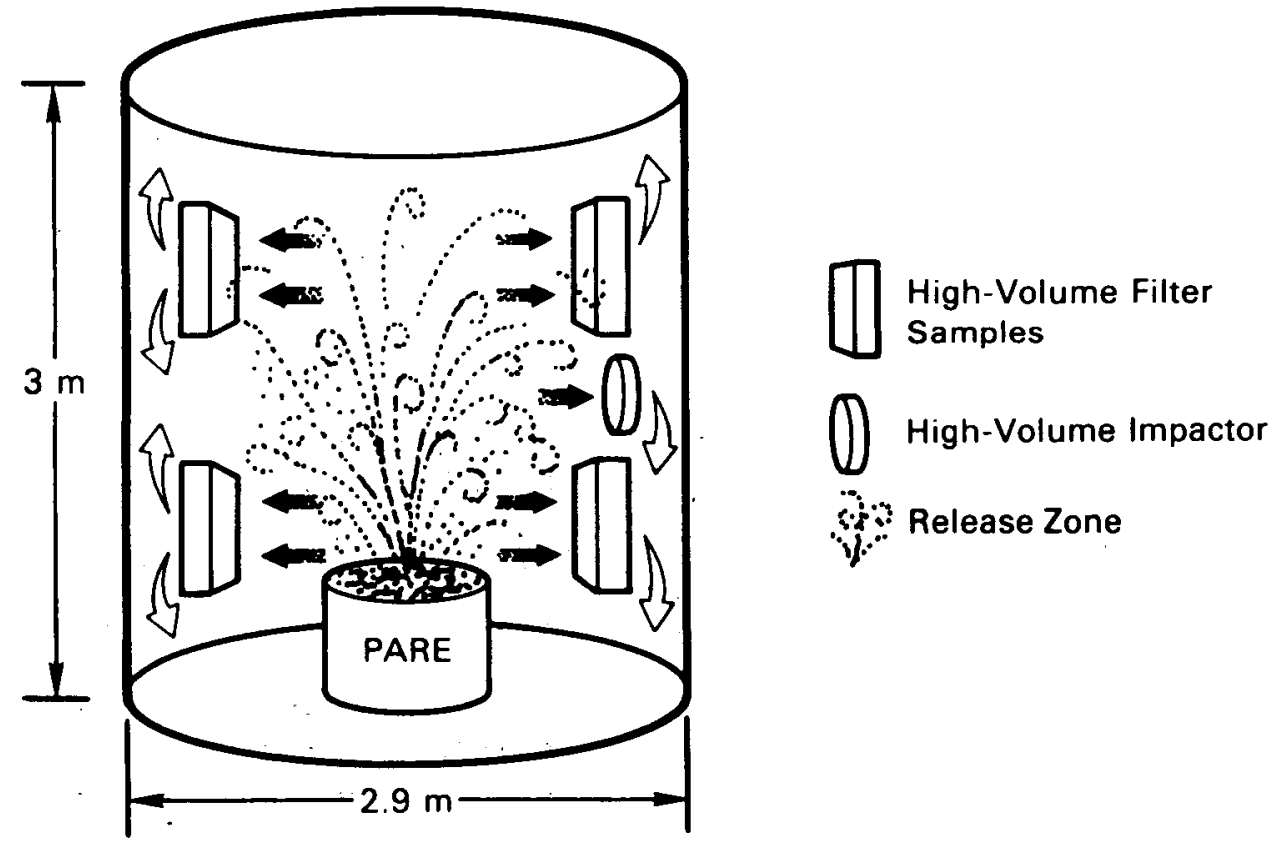

FIGURE 2.2. Sampling for a Pressurized Release with High-Volume Samplers 
at the 1.5-m level (Figure 2.2)]. Eight RART volumes of air were pulled through the samplers in a 30-min run; this is the same sampling time used for earlier liquid releases.

High-speed photography was also used to better understand results. Visual records can confirm and help explain the data analysis results.

\subsubsection{Sample Analysis}

Uranine collected on the filters was dissolved in water and analyzed by use of a calibrated fluorometer. The lower detection limit is about $1 \times 10^{-9} \mathrm{~g} / \mathrm{cm}^{3}$. Equations for the measured values at each of four fluorometer ranges were formulated and used for calculating results. The $\mathrm{R}^{2}$ values (correlation between observed and predicted values) for each attenuation curve approached 1 , indicating a good fit for the calibration standards.

Carbon dioxide used as a pressurizing gas could acidify the sample solutions and lead to problems with the analysis. Fluorescein fluorescence intensity increases sharply above a $\mathrm{pH}$ of 3 and is fairly constant between $\mathrm{pH} 6$ and 8 (Feverstein and Selleck 1963). Therefore, the pH of each collected sample was measured before the sample was analyzed to ensure that it was in the neutral range. All solutions were neutral at the time they were collected. The results of the analysis is discussed in Section 3.1 .1 .

\subsection{FLASHING-SPRAY RELEASES}

The PARE used in earlier work was modified, as shown in Figure 2.3, to permit measurement of temperature of the liquid and the vapor pressure above the liquid surface. A 1/16-in.-dia sheathed thermocouple was inserted through the bottom air inlet and sealed with a 1/8-in.-dia tubing fitted with a Teflon ${ }^{\circledR}$ compression gasket. Use of the Teflon gasket permitted adjustment of the thermocouple location.

A pressure transducer was located about $16 \mathrm{in}$. from the PARE and was attached to the PARE through a $1 / 4-i n$.-dia steel tubing with a "T" to permit pressure relief into the atmosphere with a remotely operated solenoid valve. An extension of this tube placed the opening above the liquid surface level when $700 \mathrm{~mL}$ of uranine was placed in the PARE.

Two 4-ft sections of 1-in.-wide heating tape were wrapped around the PARE body. The heating tape and other exposed metal surfaces were surrounded by loosely packed glass wool. Electrical energy for the heat tapes was remotely controlled. with variable transformers.

(3) Trademark of DuPont de Nemours. 


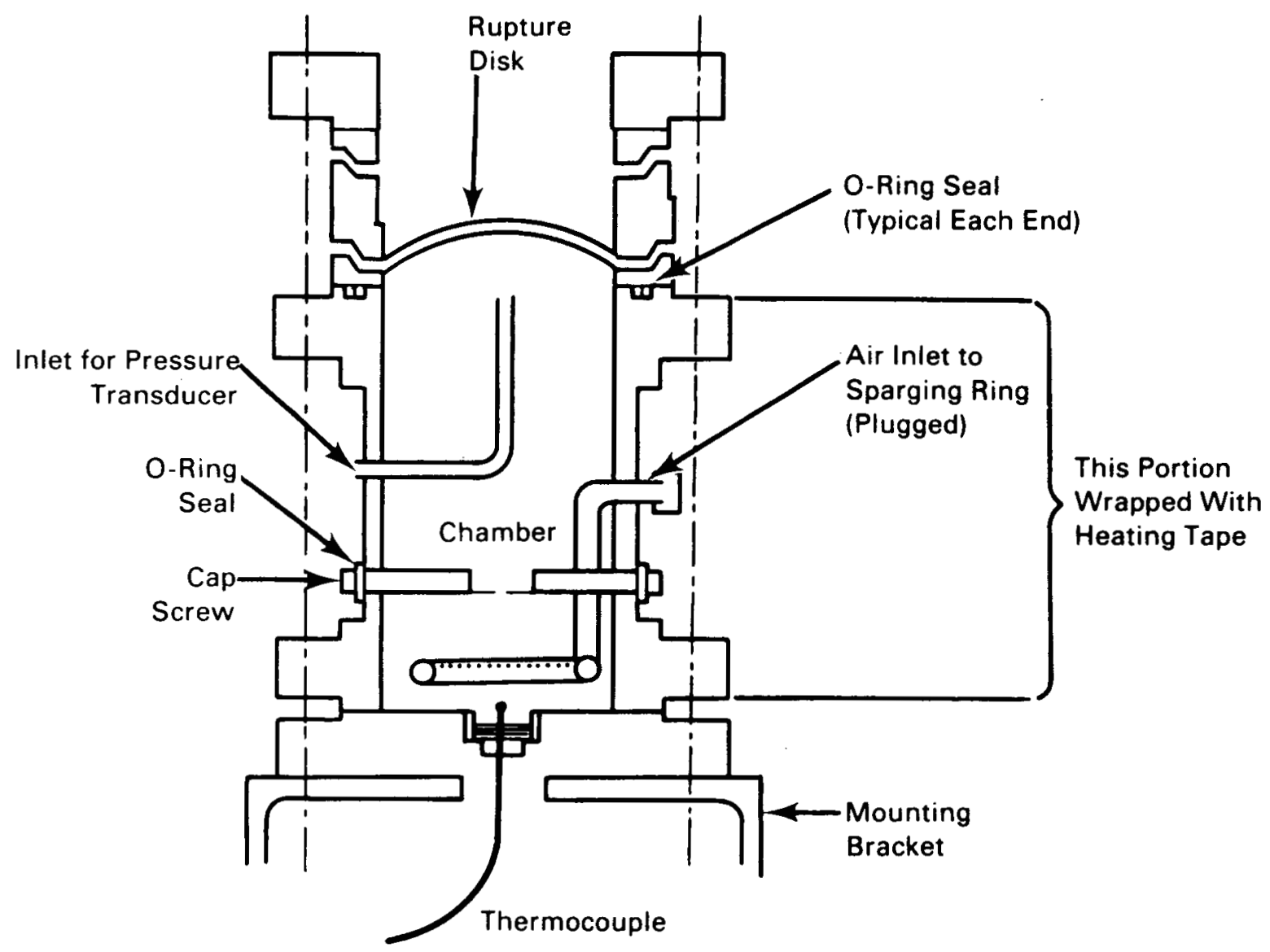

FIGURE 2.3. PARE Modifications for Flashing-Spray Release Experiments

Uranine solutions with a concentration of $10 \mathrm{~g} / \mathrm{L}$ were used for these experiments. Three volumes of 100,350 , and $700 \mathrm{~cm}^{3}$ of liquid were used. The 100 and $350 \mathrm{~cm}^{3}$ volumes enabled direct comparison of the results with previous experiments. Releases occurred at 50, 100, and 250 psig.

The rupture pressure for these experiments was the vapor pressure of the superheated liquid. A computer code was developed to predict temperatures that would result in rupture of the PARE rupture discs at pressures ranging near those used in previous releases. (The code calculated vapor pressure from given solution volume and temperature.) A plot (Figure 2.4) of the pressure in pounds per square inch gage versus the temperature in degrees Celsius was constructed from the data. The temperature required to attain rupture near the desired pressure was read from the plot. Also shown in Figure 2.4 are the temperatures measured during the actual runs. Except for run 5, measured temperatures came very close to those predicted. In run 5, the thermocouple may have malfunctioned. Approximate liquid surface temperatures at rupture were 134 , 161 , and $202^{\circ} \mathrm{C}$. The themocouple used to monitor temperature was 


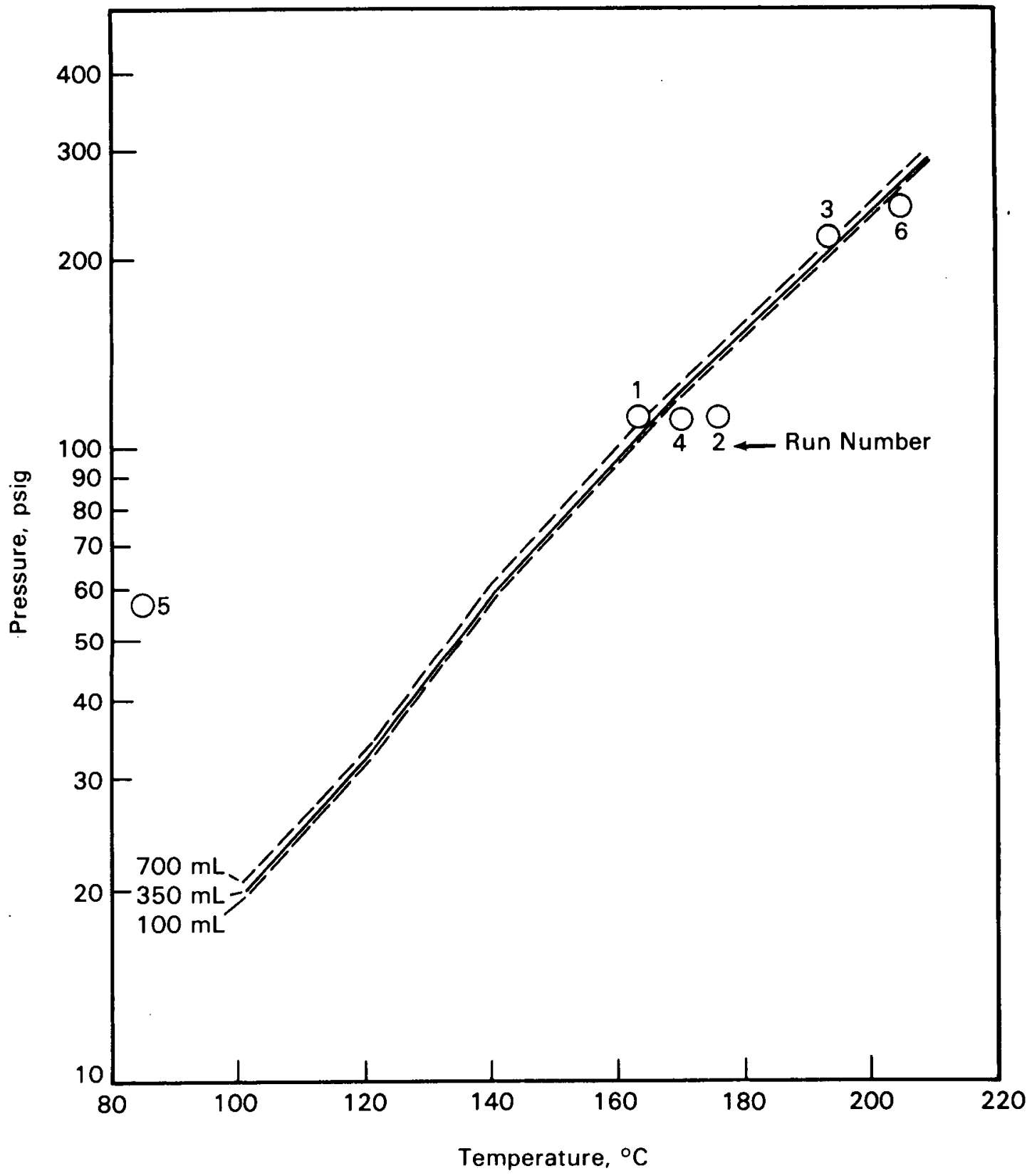

FIGURE 2.4. Measured and Predicted Temperatures for Flashing-Spray Releases

located approximately 1-1/4 in. bel ow the liquid surface before heating. Temperature was read on a potentiometer located outside the RART.

Heat was supplied to the PARE at a relatively constant rate by setting the variable transformers at $85 \%$ of maximum. Heating continued until the disk ruptured. Immediately, the heat was turned off and the samplers turned on. Sampling and analysis was the same as that for the $\mathrm{CO}_{2}$-pressurized releases. 


\subsection{LOW-PRESSURE POWDER RELEASES}

The pressurized airborne release equipment used in the $\mathrm{CO}_{2} /$ uranine and earlier releases was modified slightly for the low-pressure powder releases (Figure 2.5). The sparging ring that permitted gas to be bubbled through the uranine solution was sealed at the inlet connection. Depleted uranium dioxide powder was suspended on filter paper over a screen about $21 / 2$ in. above the air inlet that was in the base of the PARE. A single rupture disk was located in the lower rupture disk flange.

Pressures of $9,17.5$, and 24.5 psig were selected to explore the energy region between the previously reported spill and pressurized release experiments. Experimental pressures were monitored with a transducer indicator, which was calibrated before use to an accuracy of $\pm 0.5 \%$. The chamber pressure level was displayed as a digital readout. To allow direct comparison with previous experiments, 100 and $350 \mathrm{~g}$ of DuO powder were used as source quantities.

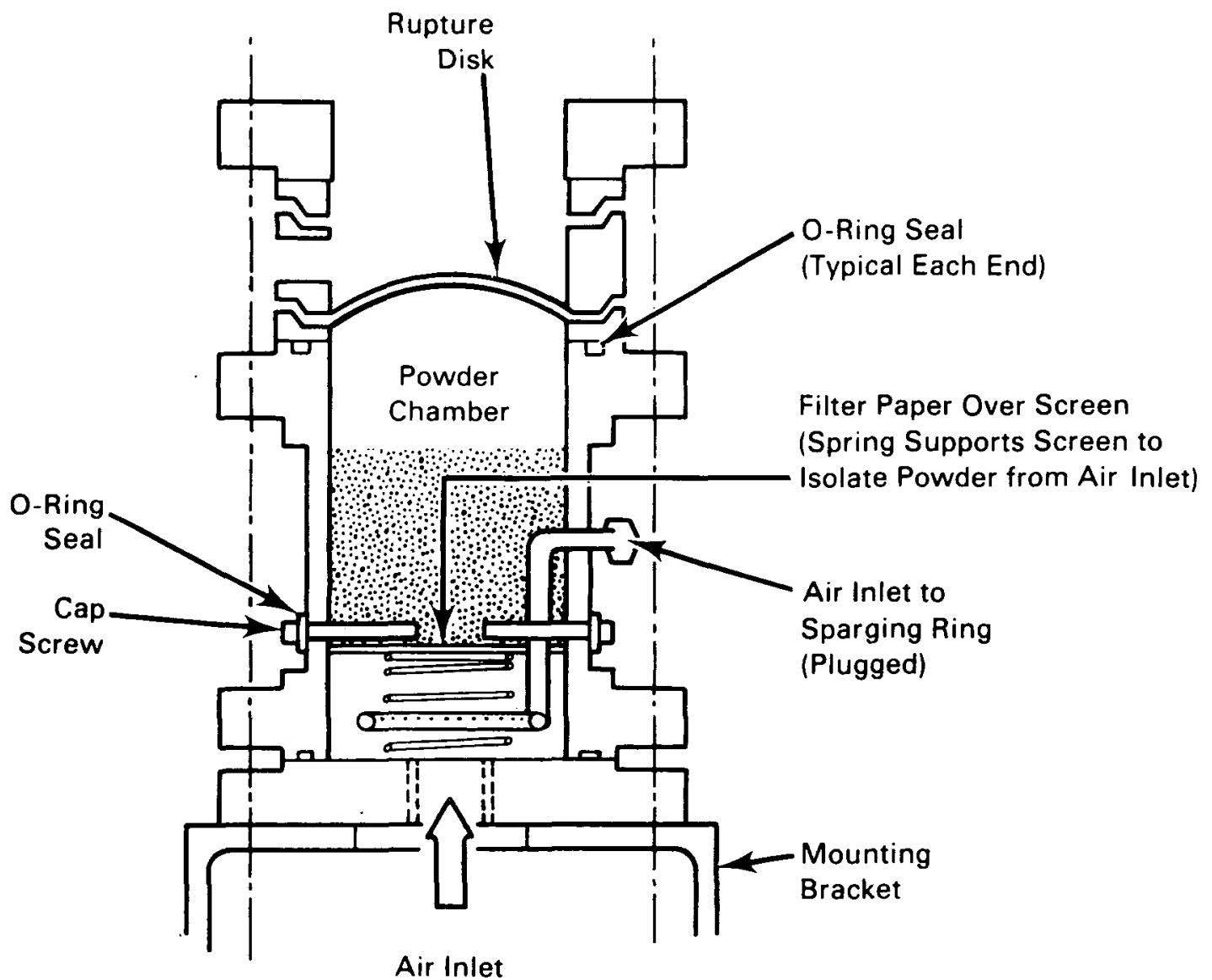

FIGURE 2.5. PARE Modification for Low-Pressure Powder Releases 
Compressed air was used as the pressurizing gas and release was accomplished by rapidly increasing pressure until rupture occurred. Sampling was similar to that for $\mathrm{CO}_{2}$-pressurized releases.

Filter samples containing collected uranium aerosols were dissolved in acid and analyzed using laser fluorometry. This method employs a pulsed nitrogen laser to excite uranium in a solution containing a pyrophosphate reagent. Fluorescent signals are amplified and integrated, and the results are displayed on a meter. Previous experiments established the experimental error to be less than $10 \%$. 


\subsection{RESULTS}

Included in this chapter are the results of the high-volume sampling of pressurized releases of liquid using $\mathrm{CO}_{2}$ as the pressurizing gas, flashing sprays, and low-pressure releases of DU0. These results will be used to develop source-term estimation models based on controlling parameters. The models will be described in a later report.

\section{$3.1 \mathrm{CO}_{2}$ /URANINE RELEASES}

Complete listings of the measured values for the uranine mass airborne are tabulated in Table A.1 in Appendix A. Values for particle size are found in Table A.2.

\subsubsection{Mass Airborne}

The total uranine mass airborne is listed in Table 3.1. The table includes average releases from air-pressurized solutions. Carbon dioxidepressurized releases were at the same or higher levels as air values and range up to eight times greater.

Carbon dioxide was used as a pressurizing gas to test the theory that the amount airborne is a function of the amount of gas dissolved in solution. Appendix $B$ shows the method of calculating the quantity of $\mathrm{CO}_{2}$ dissolved in uranine for the $\mathrm{CO}_{2}$-pressurized releases. This Appendix also gives calculations for the air-pressurized releases and for flashing sprays. When the three

TABLE 3.1. Uranine Mass (Grams) Airborne from Air- and $\mathrm{CO}_{2}-$ Pressurized Releases

$\begin{array}{ccccc}\begin{array}{c}\text { Chamber } \\ \text { Pressure, } \\ \text { psig }\end{array} & \frac{350 \mathrm{~cm}^{3}}{1.67 \times 10^{-3}} \frac{\mathrm{CO}_{2}}{4.7 \times 10^{-3}} & \frac{\mathrm{Air}}{1.5 \times 10^{-3}} & \frac{\mathrm{CO}_{2}}{2.2 \times 10^{-3}} \\ 500 & 3.3 \times 10^{-4} & 1.4 \times 10^{-3} & 6.0 \times 10^{-4} & 5.0 \times 10^{-3} \\ 250 & 2.8 \times 10^{-5} & 4.9 \times 10^{-5} & 5.0 \times 10^{-5} & 5.5 \times 10^{-5}\end{array}$


sets of experiments are plotted (Figure 3.1), the above theory does not appear to hold true for $\mathrm{CO}_{2}$-pressurized releases. Several factors may account for this:

- $\mathrm{CO}_{2}$-pressurized releases may have produced large particles, which settled out more quickly than the air-pressurized particles, thus less of the initially airborne solution was measured by the impactors. The fact that much more liquid was initially ejected from the PARE with $\mathrm{CO}_{2}$ releases than with air releases corroborates this theory.

- $\mathrm{CO}_{2}$ may have lowered the $\mathrm{pH}$ of the uranine sufficiently to precipitate some of the tracer out of solution before release. If this occurred, the amount airborne measured by the impactors may be underestimated since it would be based on a more dilute solution than was

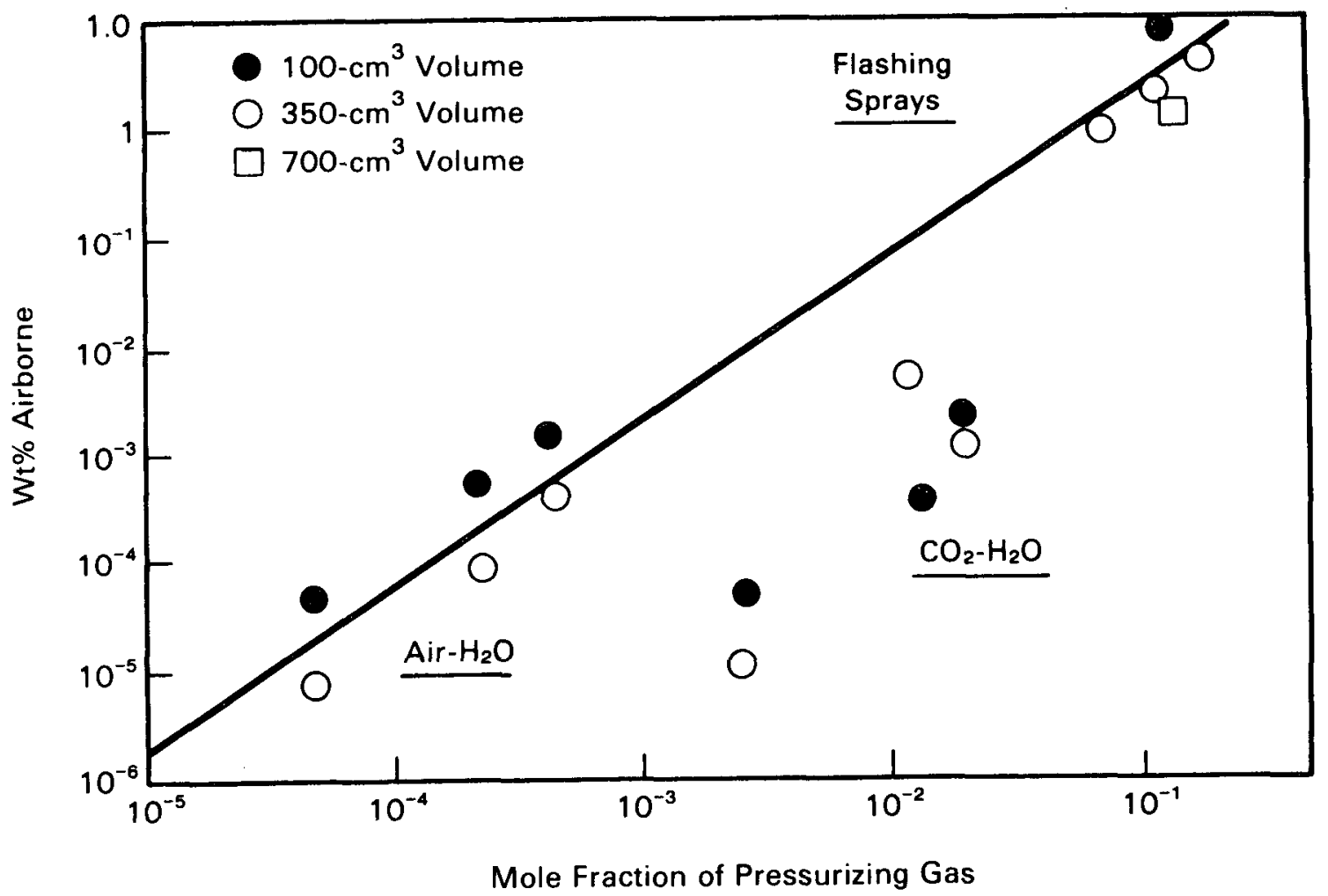

FIGURE 3.1. Weight Percent Airborne as a Function of Mole Fraction of Pressurizing Gas 
originally put in the PARE. The presence of an orange precipitate in the liquid left in the PARE during one of the runs substantiates this theory.

- The dissolved $\mathrm{CO}_{2}$ is not released as quickly as the dissolved air because of a slow reverse hydrolysis of $\mathrm{CO}_{2}$ and its reaction products with water. For example, the beverage industry depends on carbonated drinks retaining their effervescence for some time after opening.

- Much of the $\mathrm{CO}_{2}$ must have stayed in solution for some time after release. Therefore, not all of the gas dissolved in the liquid contributed to the energy available to form aerosols immediately on release. The orange precipitate mentioned above was stable in a closed container but went back into solution when the container was left open to the air. The conclusion can be made that $\mathrm{CO}_{2}$ caused sodium fluorescein to precipitate by dropping the $\mathrm{pH}$ of the solution to less than 4 . As long as the container was closed, no $\mathrm{CO}_{2}$ was allowed to escape, and the precipitate remained. When the container was open, $\mathrm{CO}_{2}$ went out of solution, the $\mathrm{pH}$ increased, and the precipitate redissolved.

The actual airborne mass could have been higher than that measured at the upper pressures since the release impacted on the RART ceiling and spread to the task walls, dripping down the sides. In an unenclosed space, much of the solution on the ceiling would probably have become airborne. On the other hand, the enclosure effect could also have enhanced the release since the liquid column impacting on the ceiling could have generated airborne droplets.

\subsubsection{High-Speed Photography and Liquid Ejected}

High-speed photography revealed that this $\mathrm{CO}_{2}$-pressurized release is a different type of event than the air-pressurized release as a geyser effect was evident. Liquid could be seen ejected from the PARE, unlike the cloud that was produced from the air-pressurized system and was barely noticeable.

The amounts ejected from the PARE are compared for air and $\mathrm{CO}_{2}$ in Table 3.2 and $i l l u s t r a t e d$ in Figure $33^{2}$. The percent of source ejected was as high as $85 \%$ for $\mathrm{CO}_{2}\left(500 \mathrm{psig}, 350 \mathrm{~cm}^{3}\right)$ compared to $4 \%$ for the corresponding air-pressurized system. In Figure 3.2 , the volume ejected is indicated on the left ordinate; on the right is the percent ejected.

However, these measurements do not reveal the entire phenomena. The highspeed photography of $\mathrm{CO}_{2}$ pressurized releases showed that the solution jetted from the chamber, reached an apex, and fell back, with a portion falling 
TABLE 3.2. Liquid Volume Ejected from the PARE

\begin{tabular}{|c|c|c|c|c|c|c|c|c|}
\hline \multirow[b]{3}{*}{$\begin{array}{c}\text { Pressure, } \\
\text { psig } \\
\end{array}$} & \multicolumn{4}{|c|}{$350 \mathrm{~cm}^{3}$} & \multicolumn{4}{|c|}{$100 \mathrm{~cm}^{3}$} \\
\hline & \multicolumn{2}{|c|}{ Air } & \multicolumn{2}{|c|}{$\mathrm{CO}_{2}$} & \multicolumn{2}{|c|}{$\overline{A i r}$} & \multicolumn{2}{|c|}{$\mathrm{CO}_{2}$} \\
\hline & $\mathrm{cm}^{3}$ & $\begin{array}{l}\% \text { of } \\
\text { Source }\end{array}$ & $\mathrm{cm}^{3}$ & $\begin{array}{l}\% \text { of } \\
\text { Source }\end{array}$ & $\mathrm{cm}^{3}$ & $\begin{array}{l}\begin{array}{c}\% \text { of } \\
\text { Source }\end{array} \\
\end{array}$ & $\mathrm{cm}^{3}$ & $\begin{array}{l}\% \text { of } \\
\text { Source }\end{array}$ \\
\hline 500 & 14 & 4 & 298 & 85 & 5 & 5 & 52 & 52 \\
\hline 250 & 8 & 2 & 225 & 64 & 6 & 6 & 33 & 33 \\
\hline 50 & 7 & 2 & 25 & 7 & 3 & 3 & 5 & 5 \\
\hline
\end{tabular}

directly back into the chamber. Thus, some of the amount left in the PARE (all of which was assumed to have not been ejected) may have initially been airborne.

The liquid remaining within the PARE and that which pooled on the floor of the RART contained solid orange particles and was foamy. The solid particles may be precipitated fluorescence. Following the release, the foam dissipated, and the solid became redissolved.

\subsubsection{Weight Percent Airborne}

Release models under development at PNL estimate the weight percent of the source airborne. The weight percent airborne values generated in these experiments are listed in Table 3.3 along with the corresponding values for the airpressurized system.

The weight percent airborne was usually larger for the smaller source for both aj $\mathrm{r}$ and $\mathrm{CO}_{2}$. Percent airborne values ranged from $0.0008(0.0028 \mathrm{~g}$ from $350 \mathrm{~cm}^{3}$ of liquid, air pressure $\left.50 \mathrm{psig}\right)$ to $0.5 \%\left(0.5 \mathrm{~g}\right.$ from $100 \mathrm{~cm}^{3}$ liquid, $\mathrm{CO}_{2}$ pressure 250 psig). The values increased with pressure as anticipated, with the exception of the $250 \mathrm{psig}$ release from a $100 \mathrm{~cm}^{3}$ source. However, the 500 psig release might have been higher in a larger enclosure that did not allow ceiling deposition or lower if significant numbers of small particles were produced by the impact.

\subsubsection{Particle Size Airborne}

Median AED particle sizes generated by the air-and $\mathrm{CO}_{2}$-pressurized liquid releases are listed in Table 3.4 and are in the same range for both gases. However, the $\sigma \mathrm{g}$ values for the $\mathrm{CO}_{2}$-pressurized releases range from 2.6 to 11 compared to the range of average values of 1.9 to 3.5 for air. This range of 


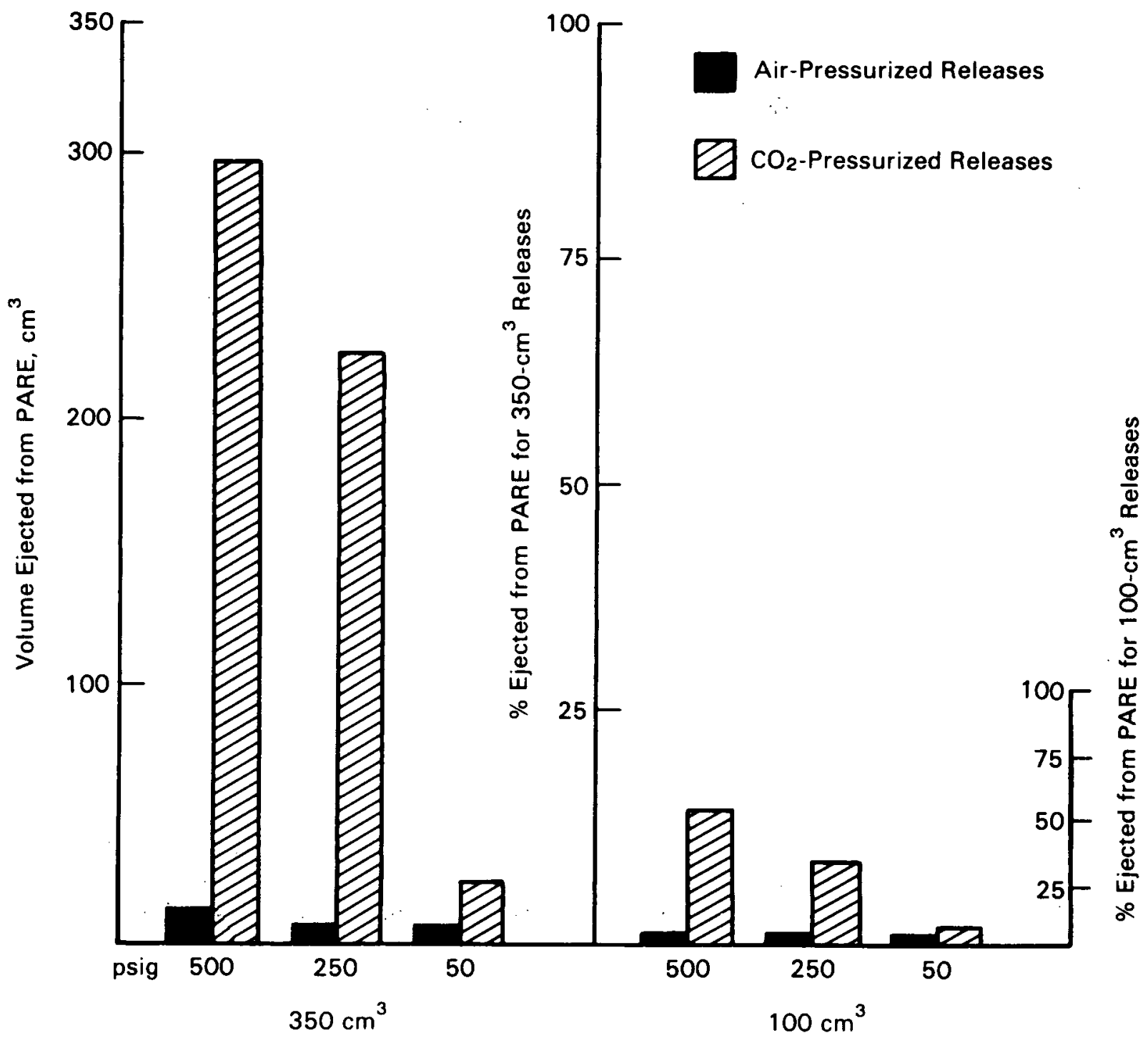

FIGURE 3.2. Solution Volumes Ejected from PARE in Air- and $\mathrm{CO}_{2}-$ Pressurized Releases

TABLE 3.3: Weight Percent Airborne from Air- and $\mathrm{CO}_{2}-$ Pressurized Releases

\begin{tabular}{clllll}
$\begin{array}{c}\text { Chamber } \\
\text { Pressure, } \\
\text { psig }\end{array}$ & $\frac{2}{2} 350 \mathrm{~cm}^{3}$ & & \multicolumn{2}{c}{$100 \mathrm{~cm}^{3}$} \\
\cline { 1 - 1 } & $\frac{\mathrm{Air}}{0.05}$ & $\frac{\mathrm{CO}_{2}}{0.13}$ & $\frac{\mathrm{CO}_{2}}{0.15}$ & $\frac{\mathrm{CO}_{2}}{0.22}$ \\
250 & 0.01 & 0.039 & 0.06 & 0.50 \\
50 & 0.0008 & 0.014 & 0.005 & 0.006
\end{tabular}


TABLE 3.4. Median AED of Particles Generated by Air- and $\mathrm{CO}_{2}-\mathrm{Pressurized}$ Liquid Releases

\begin{tabular}{|c|c|c|c|c|c|c|c|c|}
\hline \multirow{3}{*}{$\begin{array}{l}\text { Chamber } \\
\text { Pressure, } \\
\text { psig }\end{array}$} & \multicolumn{4}{|c|}{$350 \mathrm{~cm}^{3}$} & \multicolumn{4}{|c|}{$100 \mathrm{~cm}^{3}$} \\
\hline & \multicolumn{2}{|c|}{ Air } & \multicolumn{2}{|c|}{$\mathrm{CO}_{2}$} & \multicolumn{2}{|c|}{ Air } & \multicolumn{2}{|c|}{$\mathrm{CO}_{2}$} \\
\hline & $\mu \mathrm{m}$ & $\sigma \mathrm{g}$ & $\mu \mathrm{m}$ & $\sigma \mathrm{g}$ & $\mu \mathrm{m}$ & $\sigma \mathrm{g}$ & $\mu \mathrm{m}$ & $\sigma \mathrm{g}$ \\
\hline 500 & 4 & 2.7 & 3.3 & 11 & 4 & 3.5 & 2.7 & 5.5 \\
\hline 250 & 4 & 2.3 & 2.3 & 5.2 & 3 & 3.8 & 2.1 & 2.6 \\
\hline 50 & 2 & 3.5 & 1.5 & 3.8 & 2 & 4 & 1.9 & 3.3 \\
\hline
\end{tabular}

values indicates that the air vaporization produced a more uniform aerosol; it could also indicate that there is more than one particle formation process operating in the $\mathrm{CO}_{2}$ release.

High-speed photography verified the experimental results. The $\mathrm{CO}_{2}$ produced a column of uranine solution, which broke of $f$ into large chunks and droplets. While a large fraction of the source was ejected, it did not produce a large amount of fine aerosol as might have been anticipated. Energy input is required to eject the liquid and produce fine particles.

The particle-size distributions were measured by using the cascade impactor samples and may not be representative of the size distribution of the initial airborne liquid droplets. Significant evaporation of the droplets before they are captured in the impactor could mean that the measured size distribution does not correspond to that of the actual airborne aerosol. Corrections to the size distribution will be handled in model development.

\subsection{FLASHING-SPRAY RELEASES}

Complete listings of the measured values for the uranine mass airborne of superheated liquids are tabulated in Table A.3 in Appendix A. Values for particle size are found in Table A.4 in Appendix A.

\subsubsection{Mass Airborne}

Total uranine mass airborne for the flashing-spray experiments is listed in Table 3.5. The mass of uranine made airborne in these experiments is about 100-fold greater than in previous pressurized gas releases. The additional energy provided by the elevated temperature was sufficient to eject the liquid and produce the fine particles that remined suspended. 
TABLE 3.5. Mass of Uranine Made Airborne by Flashing Sprays of Superheated Liquid

\begin{tabular}{|c|c|c|c|}
\hline $\begin{array}{l}\text { Chamber } \\
\text { Pressure, } \\
\text { psig } \\
\end{array}$ & $\begin{array}{c}700-\mathrm{cm}^{3} \\
\text { Source, } \\
\mathrm{g}\end{array}$ & $\begin{array}{c}350-\mathrm{cm}^{3} \\
\text { Source, } \\
\mathrm{g}\end{array}$ & $\begin{array}{c}100-\mathrm{cm}^{3} \\
\text { Source, } \\
\mathrm{g}\end{array}$ \\
\hline $\begin{array}{r}240 \\
124 \\
57\end{array}$ & $9.68 \times 10^{-2}$ & $\begin{array}{l}1.58 \times 10^{-1} \\
7.12 \times 10^{-2} \\
2.85 \times 10^{-2}\end{array}$ & $7.83 \times$ \\
\hline
\end{tabular}

\subsubsection{Liquid Ejection}

As with previous experiments involving pressurized-uranine solutions, some of the solution impacted on the RART ceiling and spread to the walls. Only one run (57 psig) had uranine left in the PARE after release. For this run, $76 \%$ of the $350-\mathrm{cm}^{3}$ source was ejected from the PARE. The residual heat in the PARE following the release may have evaporated remaining uranine solution from most of the runs; however, visual observation of the interior of the PARE following sampling did not show a large amount of residue, which would be expected if significant evaporation took place.

\subsubsection{Weight Percent Airborne}

The values for weight percent of uranine airborne in the liquid-pressurized release experiments are plotted in Figure 3.3. Weight percent uranine airborne from flashing sprays is listed in Table 3.6. Values for flashing sprays are one and one-half to two orders of magnitude higher than for air- and $\mathrm{CO}_{2}$-pressurized releases.

The amount of pressurizing gas in the liquid was calculated for flashing sprays (see Appendix B). Figure 3.1 shows a plot of weight percent airborne versus mole fraction of pressurizing gas for three sets of data: flashing sprays, air-, and $\mathrm{CO}_{2}$-pressurized releases. A straight line with correlation coefficient $\left(R^{2}\right)$ of $98 \%$ can be drawn through the air-pressurized releases and flashing-spray data as shown in the figure. The source term from these two sets of experiments seems to be influenced by the amount of gas dissolved in the liquid. The measured amount of airborne from the $\mathrm{CO}_{2}$-pressurized releases may be conservative for the reasons specified in Section 4.3 .

\subsubsection{Particle Size Airborne}

Median AED particle sizes generated by flashing-spray releases are listed in Table 3.7 and are approximately double the values for air- and $\mathrm{CO}_{2}-$ pressurized releases. 


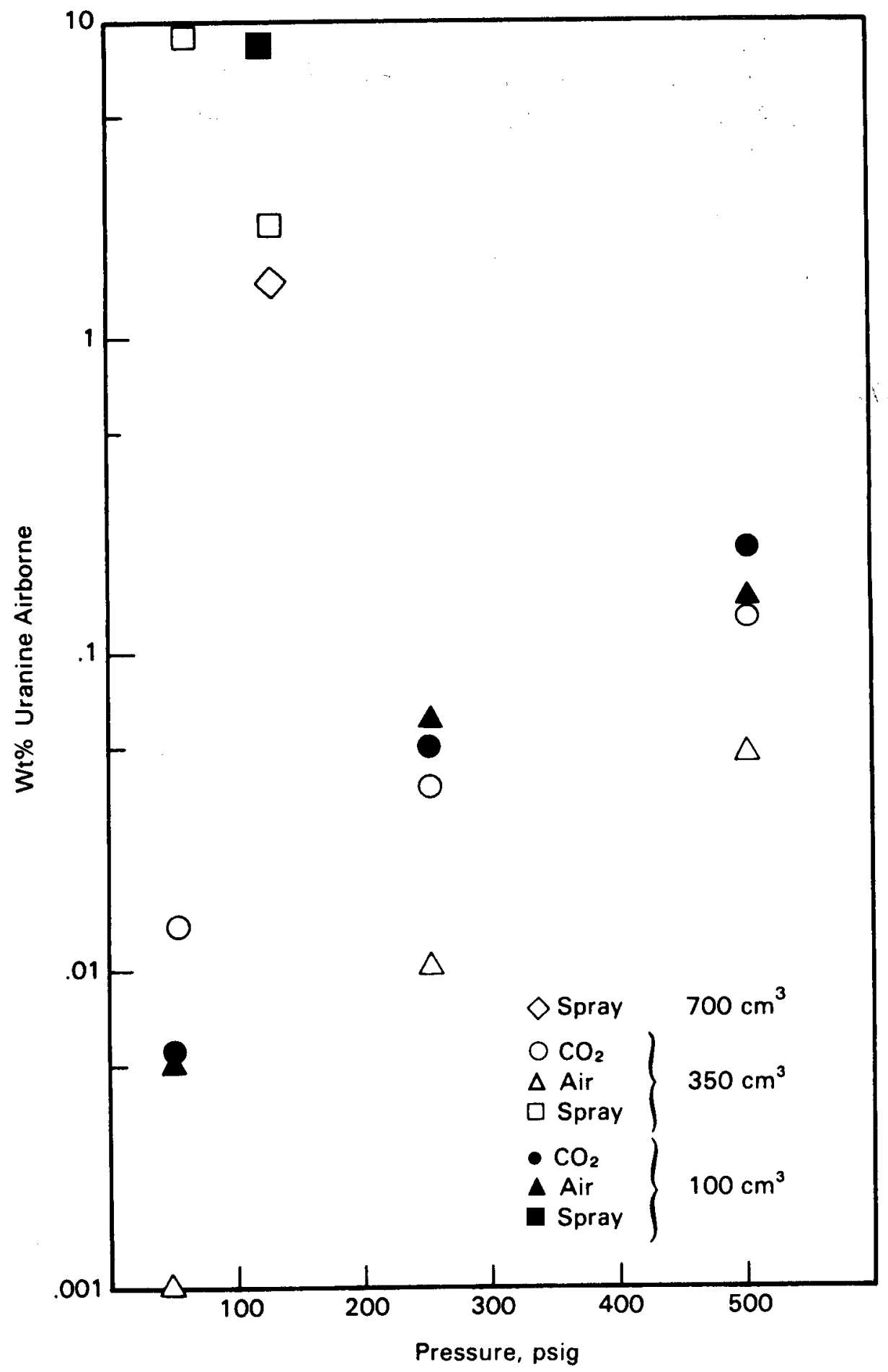

FIGURE 3.3. Weight Percent of Uranine Airborne in Liquid-Pressurized Releases 
TABLE 3.6. Weight Percent Uranine Airborne from Flashing-Spray Releases

\begin{tabular}{|c|c|c|c|}
\hline $\begin{array}{c}\text { Chamber } \\
\text { Pressure, } \\
\text { psig } \\
\end{array}$ & $\begin{array}{l}700-\mathrm{cm}^{3} \\
\text { Source }\end{array}$ & $\begin{array}{l}350-\mathrm{cm}^{3} \\
\text { Source }\end{array}$ & $\begin{array}{l}100-\mathrm{cm}^{3} \\
\text { Source }\end{array}$ \\
\hline 240 & & 4.96 & \\
\hline 124 & 1.51 & 2.22 & 8.51 \\
\hline 57 & & 0.89 & \\
\hline
\end{tabular}

TABLE 3.7. Median AED of Particles Generated by Flashing-Spray Releases

\begin{tabular}{|c|c|c|c|c|c|c|}
\hline \multirow{2}{*}{$\begin{array}{l}\text { Chamber } \\
\text { Pressure, } \\
\text { psig }\end{array}$} & \multicolumn{2}{|c|}{$\begin{array}{l}700-\mathrm{cm}^{3} \\
\text { Source }\end{array}$} & \multicolumn{2}{|c|}{$\begin{array}{l}350-\mathrm{cm}^{3} \\
\text { Source }\end{array}$} & \multicolumn{2}{|c|}{$\begin{array}{l}100-m^{3} \\
\text { Source }\end{array}$} \\
\hline & $\overline{\mathrm{AMM} \beta \mu \mathrm{m}}$ & $\sigma_{a}$ & $A m m \beta \mu m$ & $\sigma_{a}$ & $\overline{A m m \beta} \mu m$ & $\overline{\sigma_{a-}}$ \\
\hline 24 & & & 6.25 & 2.7 & & \\
\hline $\begin{array}{r}124 \\
57\end{array}$ & 5.9 & 2.6 & $\begin{array}{l}7.7 \\
8.4\end{array}$ & $\begin{array}{l}2.7 \\
5.6\end{array}$ & 6.4 & 3.3 \\
\hline
\end{tabular}

The intermediate- and high-pressure releases had $\sigma_{g}$ values ranging from 2.6 to 3.3 , the indicated uniform aerosol size. The low-pressure release $\sigma_{g}$ value was higher than all others.

\subsection{LOW-PRESSURE DUO RELEASES}

A complete listing of the measured values for the uranine mass airborne are tabulated in Table A.5 in Appendix A. Values for the particle size are found in Table A.6 in Appendix A.

\subsubsection{Mass Airborne}

The average DU0 mass airborne is tabulated in Table 3.8. Both the table and figure include average releases of previous higher pressure releases. The low-pressure releases show a greater dependence on pressure on a $\log -\log$ scale than those at higher pressures. The quantity of powdered uranium airborne falls in the range between the higher pressure releases and previous powder spills. 
TABLE 3.8. Average DUO Mass Airborne from Pressurized Powder Releases

\begin{tabular}{|c|c|c|}
\hline $\begin{array}{l}\text { Chamber } \\
\text { Pressure, } \\
\text { psig }\end{array}$ & $\begin{array}{c}350-g \\
\text { Source Duo, } \\
\mathrm{g} \\
\end{array}$ & $\begin{array}{c}100-\mathrm{g} \\
\text { Source DU0, } \\
\mathrm{g} \\
\end{array}$ \\
\hline 500.0 & 30.2 & 19.8 \\
\hline 250.0 & 20.5 & 13.0 \\
\hline 50.0 & 6.9 & 3.6 \\
\hline 24.5 & 0.61 & 0.30 \\
\hline 17.5 & 0.39 & 0.06 \\
\hline 9.0 & 0.02 & 0.03 \\
\hline
\end{tabular}

\subsubsection{Weight Percent Airborne}

The weight percent airborne values generated in these experiments are listed in Table 3.9 and plotted in Figure 3.4. For all but the 17.5-psig release, the weight percent for the smaller source shows that a larger portion becomes airborne; this is probably a result of the enclosure effect. A larger source requires more distance to disperse. Weight percent of powdered uranium airborne falls in the range between the higher pressure releases and previous powder spills.

\subsubsection{Particle Size Distribution and Powder Ejected}

Average values of the mass median AED are tabulated in Table 3.10. The release at 24.5 psig gave the highest median aerodynamic equivalent diameter for both source volumes.

At 24.5 psig, 79 to $93 \%$ of the DUO powder was ejected. At $17.5 \mathrm{psig}$, the range dropped to 35 to $86 \%$. At 9 psig, only $24 \%$ was ejected. 
TABLE 3.9. Average Weight Percent Airborne from Pressurized DUO Releases

$\begin{array}{ccc}\begin{array}{c}\text { Chamber } \\ \text { Pressure, } \\ \text { psig }\end{array} & \begin{array}{l}350-g \\ \text { Source }\end{array} & \begin{array}{l}100-\mathrm{g} \\ \text { Source }\end{array} \\ \begin{array}{c}9.0 \\ 250.0\end{array} & 6.0 & 13.0 \\ 50.0 & 2.0 & 4.0 \\ 24.5 & 0.2 & 0.3 \\ 17.5 & 0.1 & 0.06 \\ 9.0 & 0.006 & 0.03\end{array}$




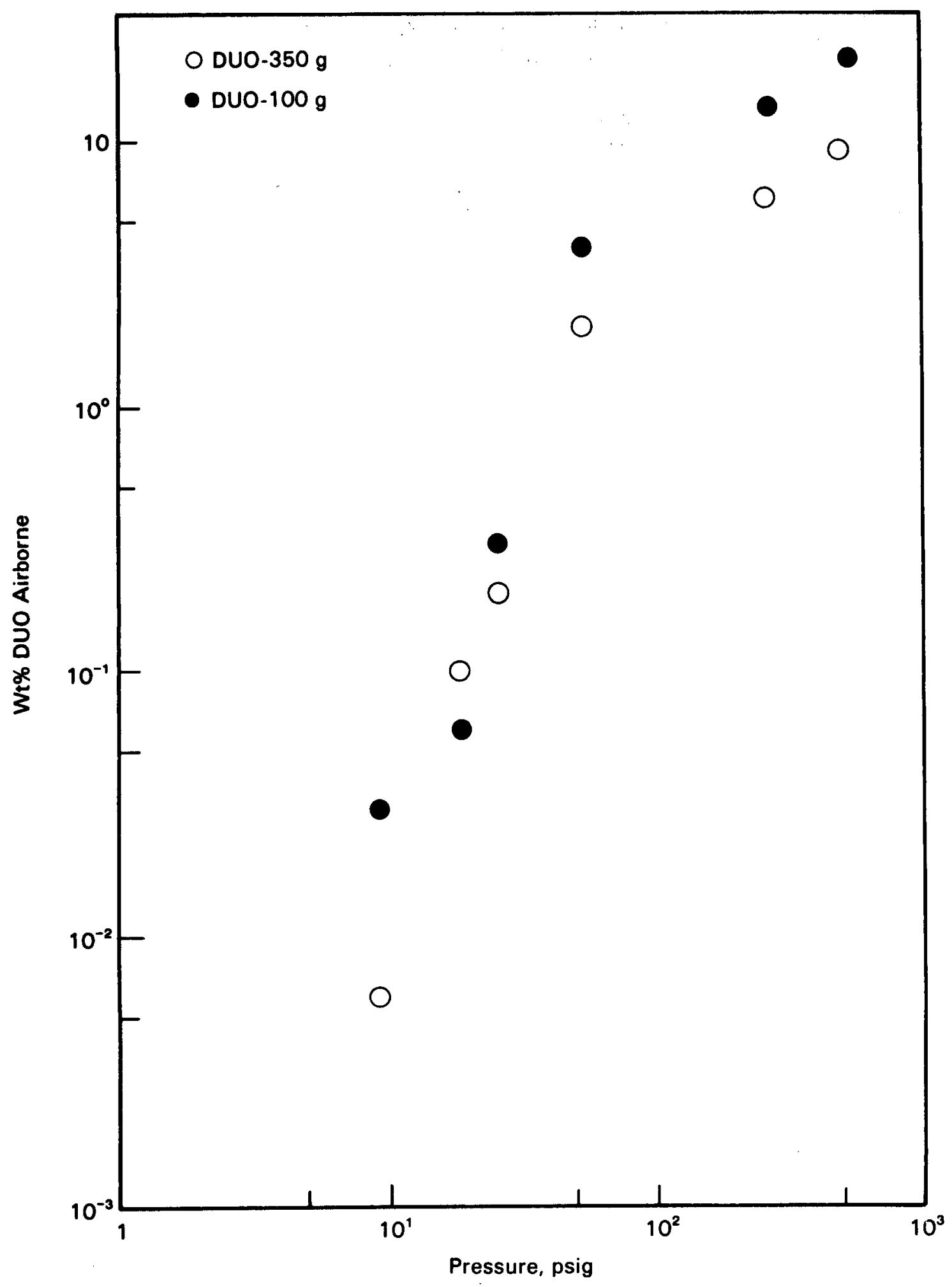

FIGURE 3.4. Weight Percent DUD Airborne Versus Pressure 
TABLE 3.10. Average Median AED of Particles Generated by

Pressurized Powder Releases, $\mu \mathrm{m}$

\begin{tabular}{|c|c|c|}
\hline $\begin{array}{c}\text { Chamber } \\
\text { Pressure, } \\
\text { psig } \\
\end{array}$ & $\begin{array}{l}350-\mathrm{g} \\
\text { Source } \\
\end{array}$ & $\begin{array}{l}100-\mathrm{g} \\
\text { Source }\end{array}$ \\
\hline 500.0 & 16 & 14 \\
\hline 250.0 & 15 & 11 \\
\hline 50.0 & 19 & 19 \\
\hline 24.5 & 38 & 24 \\
\hline 17.5 & 19 & 6 \\
\hline 9.0 & 6 & 7 \\
\hline
\end{tabular}




\subsection{REFERENCES}

Feverstein, D. L., and R. E. Selleck. 1963. "Fluorescent Tracers for Dispersion Measurements." J. of Sanitary Eng. Division, Proc. of the Am. Soc. of Civil Eng. 3586(SA 4):1-21.

Sutter, S. L. 1983. Aerosols Generated by Releases of Pressurized Powders and Solutions in Static Air. NUREG/CR-3093, U.S. Nuclear Regulatory Commission, Washington, D.C.

Sutter, S. L., J. W. Johnston and J. Mishima. 1981. Aerosols Generated by Free Fall Spills of Powders and Solutions in Static Air. NUREG/CR-2651, U.S. Nuclear Regulatory Commission, Washington, D.C. 


\section{APPENDIX A}

EXPER IMENTAL DATA 
EXPER IMENTAL DATA

TABLE A.1. Mass Airborne from $\mathrm{CO}_{2}-$ Pressurized Releases of Uranine Solutions

\begin{tabular}{|c|c|c|c|c|c|c|}
\hline $\begin{array}{l}\text { Source } \\
\text { Volume, } \\
\mathrm{cm}^{3}\end{array}$ & $\begin{array}{l}\text { Pressure, } \\
\text { psig }\end{array}$ & $\begin{array}{c}\text { Uranine } \\
\text { Collected, } \\
\mathrm{g}\end{array}$ & $\begin{array}{c}\text { Wt\% } \\
\text { Airborne }\end{array}$ & $\begin{array}{c}\text { Total } \\
\text { Volume } \\
\text { Ai rborne, } \\
\mathrm{cm}^{3}\end{array}$ & $\begin{array}{c}\text { Volume not } \\
\text { Ejected } \\
\text { from } \\
\text { Chamber, } \\
\mathrm{cm}^{3}\end{array}$ & $\begin{array}{c}\text { Volume } \\
\text { Ejected } \\
\text { but not } \\
\text { Airborne }(b) \\
\end{array}$ \\
\hline \multirow[t]{3}{*}{350} & 500 & $4.7 \times 10^{-3}$ & 0.13 & 0.46 & 52 & 297.54 \\
\hline & 250 & $1.4 \times 10^{-3}$ & 0.039 & 0.14 & 125 & 224.74 \\
\hline & 50 & $4.9 \times 10^{-5}$ & 0.0014 & 0.005 & 325 & 25.0 \\
\hline \multirow[t]{3}{*}{100} & 500 & $2.2 \times 10^{-3}$ & 0.22 & 0.22 & $48^{(c)}$ & 51.78 \\
\hline & 250 & $5.0 \times 10^{-3}$ & 0.50 & 0.50 & 67 & 32.5 \\
\hline & 50 & $5.5 \times 10^{-5}$ & 0.0055 & 0.0055 & 95 & 5.0 \\
\hline
\end{tabular}

(a) Uranine solution density $0.99 \mathrm{~g} / \mathrm{cm}^{3}$.

(b) Estimated from volume airborne and amount not ejected from PARE.

(c) Under purge ring, modified after run.

TABLE A.2. Median AED of Particles Produced by $\mathrm{CO}_{2}$-Pressurized Releases of Uranine Solutions

\begin{tabular}{|c|c|c|c|c|c|}
\hline $\begin{array}{l}\text { Source } \\
\text { Volume, } \\
\mathrm{cm}^{3} \\
\end{array}$ & $\begin{array}{c}\text { Pressure, } \\
\text { psig } \\
\end{array}$ & $\begin{array}{c}\text { Medi am } \\
\text { Di ameter, } \\
\mu \mathrm{m} \\
\end{array}$ & $\sigma_{g}$ & $\begin{array}{l}\% 10 \mu \mathrm{m} \\
\text { and Less }\end{array}$ & $\begin{array}{l}\text { Wt\% of Source } \\
\text { that Becomes } \\
\text { Airborne and is } \\
10 \mu \mathrm{m} \text { and Less }\end{array}$ \\
\hline 350 & 500 & 3.3 & 11.0 & 68 & 0.088 \\
\hline 250 & 2.3 & 5.2 & 82 & 0.032 & \\
\hline 50 & 1.5 & 3.8 & 92 & 0.0013 & \\
\hline 100 & 500 & 2.7 & 5.5 & 78 & 0.17 \\
\hline 250 & 2.1 & 2.6 & 95 & 0.48 & \\
\hline 50 & 1.9 & 3.3 & 92 & 0.0046 & \\
\hline
\end{tabular}


TABLE A.3. Mass Airborne from Flashing-Spray Releases of Superheated Liquids

\begin{tabular}{|c|c|c|c|c|c|c|}
\hline $\begin{array}{l}\text { Source } \\
\text { Volume, } \\
\text { Cc }\end{array}$ & $\begin{array}{c}\text { Pressure, } \\
\text { psig } \\
\end{array}$ & $\begin{array}{c}\text { Uranine } \\
\text { Collected, } \\
\text { cc } \\
\end{array}$ & $\begin{array}{c}\text { Wt\% } \\
\text { Airborne } \\
\end{array}$ & $\begin{array}{c}\text { Total Volume } \\
\text { Ai rborne, } \\
\text { cc } \\
\end{array}$ & $\begin{array}{c}\text { Total Volume } \\
\text { not Ejected } \\
\text { from } \\
\text { Chamber, } \\
\text { cc } \\
\end{array}$ & $\begin{array}{c}\text { Volume } \\
\text { Ejected } \\
\text { but not } \\
\text { Airborne, } \\
\text { cc } \\
\end{array}$ \\
\hline 700 & 125 & $9.7 \times 10^{-2}$ & 1.51 & 7.7 & & 692.3 \\
\hline 350 & 240 & $1.6 \times 10^{-1}$ & 4.96 & 10.5 & & 339.5 \\
\hline \multicolumn{2}{|c|}{$1257.1 \times 10^{-2}$} & 2.22 & 17.2 & & 332.8 & \\
\hline \multicolumn{2}{|c|}{$602.8 \times 10^{-2}$} & 8.92 & 3.1 & 83 & 263.9 & \\
\hline 100 & 125 & $7.8 \times 10^{-2}$ & 8.51 & 8.5 & & 91.5 \\
\hline
\end{tabular}

(a) Uranine solution density $1.0 \mathrm{~g} / \mathrm{cc}$.

(b) Estimated from volume airborne and amount not ejected from PARE.

TABLE A.4. Median AED of Particles Produced by Flashing-Spray Releases of Superheated Uranine Solutions

\begin{tabular}{|c|c|c|c|c|c|}
\hline $\begin{array}{l}\text { Source } \\
\text { Volume, } \\
\text { cc } \\
\end{array}$ & $\begin{array}{c}\text { Pressure, } \\
\text { psig } \\
\end{array}$ & $\begin{array}{c}\text { Median } \\
\text { Diameter, } \\
\mu m \\
\end{array}$ & $\underline{\sigma}_{g}$ & $\begin{array}{l}\% 10 \mu \mathrm{m} \\
\text { and Less }\end{array}$ & $\begin{array}{l}\text { Wt\% of Source } \\
\text { that Becomes } \\
\text { Airborne and is } \\
10 \mu \mathrm{m} \text { and Less }\end{array}$ \\
\hline 700 & 125 & 5.9 & 2.6 & 78 & 1.18 \\
\hline \multirow[t]{3}{*}{350} & 240 & 6.2 & 2.7 & 73 & 3.63 \\
\hline & 125 & 7.7 & 2.7 & 66 & 1.46 \\
\hline & 60 & 8.4 & 5.6 & 62 & 5.53 \\
\hline 100 & 125 & 6.4 & 3.3 & 69 & 5.87 \\
\hline
\end{tabular}


TABLE A.5. Mass Airborne from Low-Pressure DUO Releases

\begin{tabular}{|c|c|c|c|c|c|}
\hline $\begin{array}{c}\text { Source } \\
\text { Mass; } \\
\mathbf{g} \\
\end{array}$ & $\begin{array}{c}\text { Pressure, } \\
\text { psi.g } \\
\end{array}$ & $\begin{array}{c}\text { Uranium } \\
\text { Collected, } \\
g \\
\end{array}$ & $\begin{array}{c}\text { Wt\% } \\
\text { Airborne }\end{array}$ & $\begin{array}{c}\text { Total Mass } \\
\text { not Ejected } \\
\text { from Chamber, } \\
\mathrm{g} \\
\end{array}$ & $\begin{array}{c}\text { Mass } \\
\text { Ejected } \\
\text { but not } \\
\text { Airborne, } \\
\mathrm{g} \\
\end{array}$ \\
\hline \multirow[t]{3}{*}{350} & 24.5 & 0.610 & 0.174 & 24.4 & 325.0 \\
\hline & 17.5 & 0.387 & 0.111 & 50.1 & 299.4 \\
\hline & $9: 0$ & 0.017 & 0.005 & 269.6 & 80.4 \\
\hline 100 & 24.5 & 0.302 & 0.302 & 21.1 & 78.7 \\
\hline & 17.5 & 0.63 & 0.63 & 65.5 & 34.4 \\
\hline & 9.0 & 0.03 & 0.03 & 75.9 & 24.1 \\
\hline
\end{tabular}

TABLE A.6. Median AED of Particles Producted by Low-Pressure DU0 Releases

\begin{tabular}{|c|c|c|c|c|c|}
\hline $\begin{array}{c}\text { Source } \\
\text { Mass, } \\
g \\
\end{array}$ & $\begin{array}{c}\text { Pressure, } \\
\text { psig } \\
\end{array}$ & $\begin{array}{c}\text { Median } \\
\text { Diameter, } \\
\mu m \\
\end{array}$ & $\sigma_{q}$ & $\begin{array}{r}\% 10 \mu \mathrm{m} \\
\text { and Less } \\
\end{array}$ & $\begin{array}{l}\text { Wt\% of Source } \\
\text { that Becomes } \\
\text { Airborne and is } \\
10 \mu \mathrm{m} \text { and Less }\end{array}$ \\
\hline \multirow[t]{3}{*}{350} & 24.5 & 38 & 9.3 & 35 & 0.061 \\
\hline & 17.5 & 19 & 6.5 & 60 & 0.067 \\
\hline & 9.0 & 6 & 6.0 & 61 & 0.003 \\
\hline \multirow[t]{3}{*}{100} & 24.5 & 24 & 7.5 & 42 & 0.127 \\
\hline & 17.5 & 6 & 4.6 & 72 & 0.045 \\
\hline & 9.0 & 7 & 4.8 & 62 & 0.02 \\
\hline
\end{tabular}


APPENDIX B

CALCULATIONS

-


APPENDIX B

CALCULATIONS

According to Henry's Law (Hougen et al. 1958), the mole fraction of a soluble gas is directly proportional to the partial pressure of that gas above the liquid surface. However, at high pressures (above 1 atmosphere) the value of Henry's Law, constant $H$, varies with temperature and pressure. In this appendix, the value of $H$ is calculated for the temperatures and pressures in the pressurized release experiments. The amount of gas dissolved in the liquid is calculated for the $\mathrm{CO}_{2}^{-}$and air-pressurized releases and flashing sprays.

\section{B.1 THE $\mathrm{CO}_{2}=\mathrm{H}_{2}$ O SYSTEM}

Pressurized releases using $\mathrm{CO}_{2}$ as the pressurized gas were run at temperature and pressure ranges of 13 to $21^{\circ} \mathrm{C}$ and 50 to $500 \mathrm{psig}$, respectively. Perry's Handbook (Perry et al. 1963) contains data on solubility of $\mathrm{CO}_{2}$ in $\mathrm{H}_{2} \mathrm{O}$ at elevated temperatures and pressures. Lange's Handbook of Chemistry (Lange and Forker 1944) contains additional data on $\mathrm{CO}_{2}$ solubility in $\mathrm{H}_{2} \mathrm{O}$ at 1 atmosphere. Data from Lange is plotted in $F$ igure $B .1$ and $1 / H$ values taken from the plot at 12,18 , and $25^{\circ} \mathrm{C}$ to add to data from Perry. Table $B .1$ lists information from both Lange and Perry.

Mole fraction $\mathrm{CO}_{2}$ in $\mathrm{H}_{2} \mathrm{O}$ is calculated from weight $\mathrm{CO}_{2}$ per 100 weight $\mathrm{H}_{2} \mathrm{O}$ by converting to moles and dividing moles $\mathrm{CO}_{2}$ by total moles. Calculations of $1 / H$ are made using Henry's Law:

$$
N=\left(\frac{1}{H}\right) P
$$

where $N$ is the mole fraction of dissolved gas, $P$ is the partial pressure of gas and atmospheres, and $H$ is the mole fraction per atmosphere.

Figure $\mathrm{B} .2$ is a $\mathrm{pl}$ ot of $1 / \mathrm{H}$ versus partial pressure of $\mathrm{CO}_{2}$ at the three temperatures that span experimental temperatures. For experimental pressures of 50,250 , and $500 \mathrm{psig}, 1 / \mathrm{H}$ for $\mathrm{CO}_{2}$ is read of the graph at each temperature and listed in Table B.2. The mole fraction of dissolved gas ( $N$ ) is then calculated for each experimental pressure using Henry's Law. This value is also given in Table B.2. Figure B.3 is a plot of mole fraction of $\mathrm{CO}_{2}$ in uranine versus temperature at each experimental pressure. From this figure, 


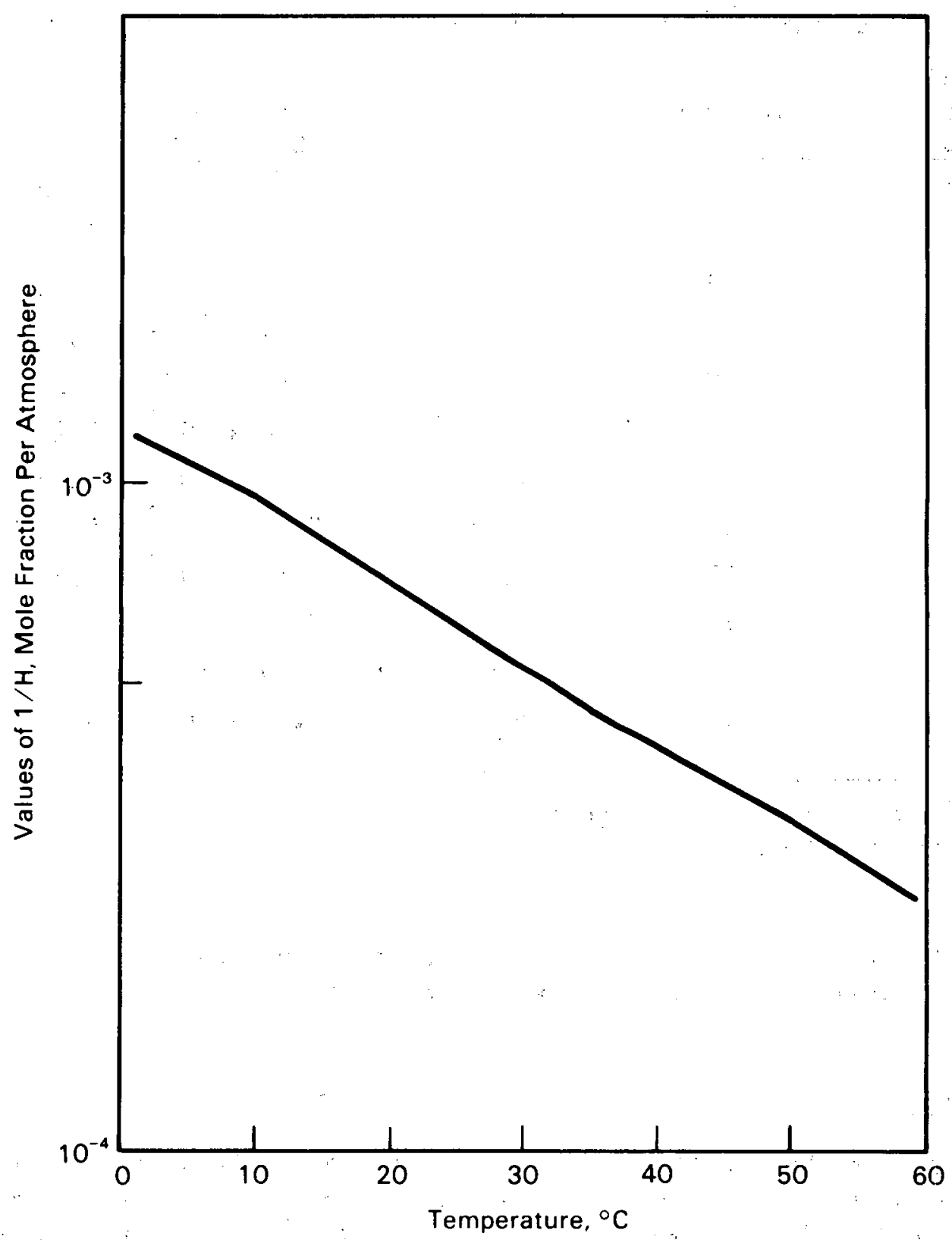

FIGURE B.1. Plot of $1 / \mathrm{H}$ Versus Temperature for $\mathrm{CO}_{2}$ Solubility in $\mathrm{H}_{2} \mathrm{O}$ at 1 Atmosphere 
TABLE B.1. Mole Fraction and $1 / H$ by Temperature and Pressure

\begin{tabular}{|c|c|c|c|c|}
\hline $\begin{array}{c}\text { Total } \\
\text { Pressure } \\
\text { Atmosphere } \\
\end{array}$ & $\begin{array}{c}\text { Temperature, } \\
{ }^{\circ} \mathrm{C}\end{array}$ & $\begin{array}{l}W t \% \mathrm{CO}_{2} \text { per } \\
100 \mathrm{Wt}^{2} \mathrm{H}_{2} \underline{\mathrm{O}} \\
\end{array}$ & $\begin{array}{c}\text { Mole } \\
\text { Fraction } \\
\mathrm{CO}_{2} \text { in } \mathrm{H}_{2} \mathrm{O}\end{array}$ & $\begin{array}{c}1 / \mathrm{H}, \text { Mole } \\
\text { Fraction Per } \\
\text { Atmosphere }\end{array}$ \\
\hline \multirow[t]{3}{*}{1} & 12 & & & $8.80 \times 10^{-4(a)}$ \\
\hline & 18 & & & $7.35 \times 10^{-4(a)}$ \\
\hline & 25 & & & $5.95 \times 10^{-4(a)}$ \\
\hline \multirow[t]{3}{*}{25} & 12 & $4.5^{(b)}$ & $1.81 \times 10^{-2}$ & $7.23 \times 10^{-4}$ \\
\hline & 18 & 3.86 & $1.55 \times 10^{-2}$ & $6.22 \times 10^{-4}$ \\
\hline & 25 & $3.22^{(b)}$ & $1.30 \times 10^{-2}$ & $5.20 \times 10^{-4}$ \\
\hline \multirow[t]{3}{*}{50} & 12 & 7.03 & $2.80 \times 10^{-2}$ & $5.59 \times 10^{-4}$ \\
\hline & 18 & 6.33 & $2.52 \times 10^{-2}$ & $5.05 \times 10^{-4}$ \\
\hline & 25 & 5.38 & $2.15 \times 10^{-2}$ & $4.31 \times 10^{-4}$ \\
\hline \multirow[t]{3}{*}{75} & 12 & 7.18 & $2.85 \times 10^{-2}$ & $3.80 \times 10^{-4}$ \\
\hline & 18 & 6.69 & $2.66 \times 10^{-2}$ & $3.55 \times 10^{-4}$ \\
\hline & 25 & 6.17 & $2.46 \times 10^{-2}$ & $3.28 \times 10^{-4}$ \\
\hline
\end{tabular}

(a) Taken di rectly from Figure B.1.

(b) Interpolated.

the mole fraction of $\mathrm{CO}_{2}$ dissolved in uranine can be read at the temperature for each experiment; Table B.3 gives these values.

\section{B.2 AIR- $\mathrm{H}_{2} \underline{\mathrm{O}}$}

Perry's Handbook (Perry et al. 1963) provides data on the solubility of nitrogen and oxygen in water. Figure $B .4$ is a plot of $H$ versus partial pressure for oxygen and nitrogen systems, respectively. The partial pressure of nitrogen and oxygen at experimental pressures is equal to the mole fraction $(0.79$ and 0.21 , respectively) multiplied by the experimental pressure. Table B.4 lists the partial pressures of $\mathrm{O}_{2}$ and $\mathrm{N}_{2}$, the value of $\mathrm{H}$ from Figure B.4 and the mole fraction of air dissolved in liquid for each experimental pressure. 


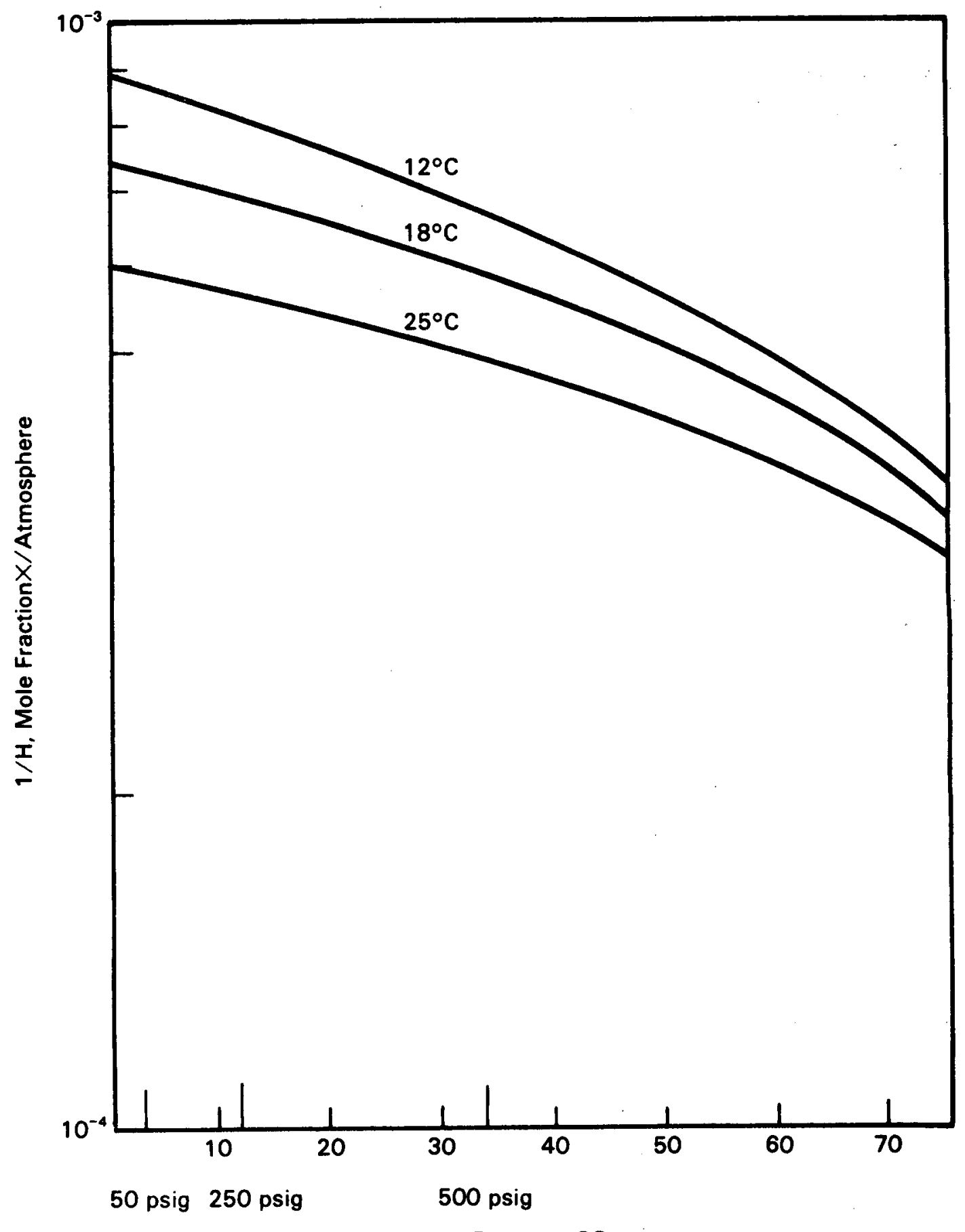

Partial Pressure $\mathrm{CO}_{2}$, atm

FIGURE B.2. 1/H Versus Partial Pressure of $\mathrm{CO}_{2}$ for Temperature Range of Experiments 
TABLE B.2. Mole Fraction of $\mathrm{CO}_{2}$ at Experimental Pressures

\begin{tabular}{|c|c|c|c|c|}
\hline \multicolumn{2}{|c|}{$\begin{array}{c}\mathrm{CO}_{2} \text { Partial Pressure } \\
\text { Over System }\end{array}$} & \multirow{2}{*}{$\begin{array}{c}\text { Temperature, } \\
{ }^{\circ} \mathrm{C} \\
\end{array}$} & \multirow{2}{*}{$\begin{array}{c}1 / \mathrm{H} \text { Mole } \\
\text { Fraction/ } \\
\text { Atmosphere } \\
\end{array}$} & \multirow{2}{*}{$\begin{array}{c}\text { Mole } \\
\text { Fraction }\end{array}$} \\
\hline psig & atm & & & \\
\hline \multirow[t]{3}{*}{50} & 3.4 & 12 & $8.68 \times 10^{-4}$ & 0.00295 \\
\hline & & 18 & $7.25 \times 10^{-4}$ & 0.0025 \\
\hline & & 25 & $5.90 \times 10^{-4}$ & 0.0020 \\
\hline \multirow[t]{3}{*}{250} & 17 & 12 & $8.10 \times 10^{-4}$ & 0.0138 \\
\hline & & 18 & $6.88 \times 10^{-4}$ & 0.0117 \\
\hline & & 25 & $5.64 \times 10^{-4}$ & 0.0096 \\
\hline \multirow[t]{3}{*}{500} & 34 & 12 & $6.65 \times 10^{-4}$ & 0.0226 \\
\hline & & 18 & $5.88 \times 10^{-4}$ & 0.0200 \\
\hline & & 25 & $4.92 \times 10^{-4}$ & 0.0167 \\
\hline
\end{tabular}

\section{B.3 FLASHING SPRAYS}

For flashing sprays, the mole fraction of gas dissolved in the liquid is equal to the fraction of vapor flashed at release. The enthalpy and volume of vapor and liquid before and directly at release are used to calculate the fraction flashed. Properties of the liquid in the PARE just before a release of $350 \mathrm{~mL}$ of uranine at $163^{\circ} \mathrm{C}$ are given as the following:

where $T=163^{\circ} \mathrm{C}=325^{\circ} \mathrm{F}$

$V_{\mathrm{g}}=4.66 \mathrm{ft}^{3} / 1 \mathrm{bm}=290.7 \mathrm{~mL} / \mathrm{g}$

$H_{\mathrm{g}}=1186.2 \mathrm{Btu} / 1 \mathrm{bm}=2.61 \mathrm{Btu} / \mathrm{g}$

$V_{L}^{g}=0.0177 \mathrm{ft}^{3} / 1 \mathrm{bm}=1.10 \mathrm{~mL} / \mathrm{g}$

$H_{L}=294.6 \mathrm{Btu} / 1 \mathrm{bm}=0.649 \mathrm{Btu} / \mathrm{g}$

Total mass in the PARE is $350 \mathrm{~g}$, and PARE volume is $800 \mathrm{~mL}$. If $x$ is the volume of vapor, then $800-x$ is the volume of liquid and $x$ can be calculated by

$$
\begin{gathered}
\frac{x}{290.7}+\frac{800-x}{1.10}=350 \\
x=290.7 \frac{(350(1.1)-800)}{(1.1-290.7)}=416.6-\mathrm{mL} \text { vapor }=1.43-\mathrm{g} \text { vapor }
\end{gathered}
$$




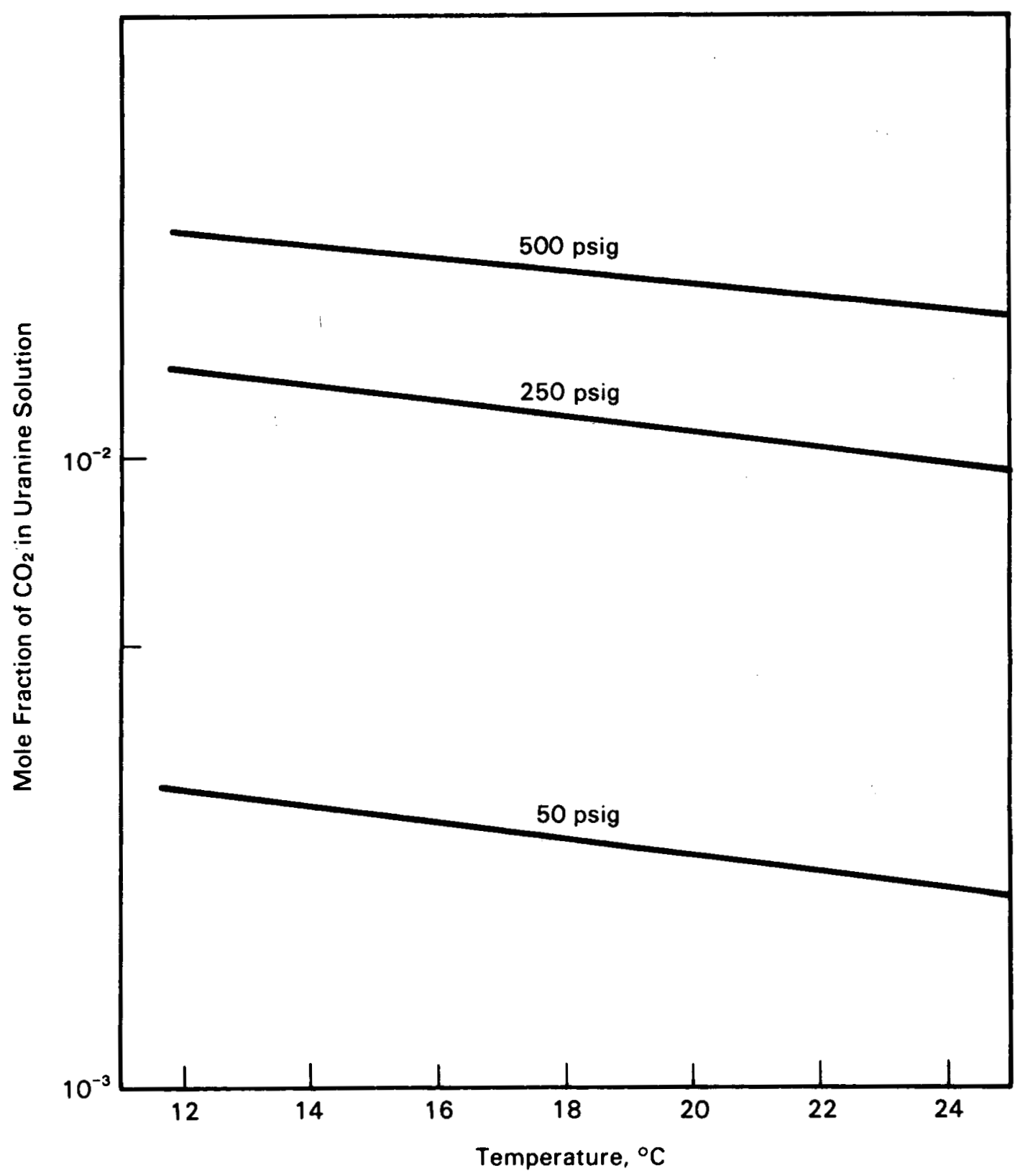

FIGURE B.3. Mole Fraction of $\mathrm{CO}_{2}$ Dissolved in Uranine Solutions Versus Temperature at Partial Pressure Indicated 
TABLE B.3. Mole Fraction of $\mathrm{CO}_{2}$ Dissolved in Uranine for $\mathrm{CO}_{2}$-Pressurized Releases

\begin{tabular}{cccccc}
$\begin{array}{c}\text { Run } \\
\text { No. }\end{array}$ & $\begin{array}{c}\text { Pressure, } \\
\text { psig }\end{array}$ & $\begin{array}{c}\text { Temperature, } \\
{ }^{\circ} \mathrm{C}\end{array}$ & $\begin{array}{c}\text { Mole } \\
\text { Fraction }\end{array}$ & $\begin{array}{c}\text { Average } \\
\text { Mole Fraction }\end{array}$ \\
\cline { 2 - 2 } & 50 & 21 & & 0.0023 & 0.0025 \\
6 & 50 & 16 & 0.00265 & \\
3 & 250 & 13 & 0.0135 & 0.0128 \\
4 & 250 & 17 & 0.0121 & \\
2 & 500 & 18 & 0.0200 & 0.0200 \\
5 & 500 & 18 & 0.0200 &
\end{tabular}

Liquid volume $=800-416.6=383.4 \mathrm{~mL}$ liquid $=348.5 \mathrm{~g}$ liquid

Total energy in the PARE is calculated as follows:

$$
E=1.43 \mathrm{~g}(2.61 \mathrm{Btu} / \mathrm{g})+348.5 \mathrm{~g}(0.649 \mathrm{Btu} / \mathrm{g})=230 \mathrm{Btu}
$$

At release, some of the uranine flashes immediately dropping the temperature to $100^{\circ} \mathrm{C}$. Properties of the liquid at this temperature are listed as follows:

$$
\begin{aligned}
T & =100^{\circ} \mathrm{C}=212^{\circ} \mathrm{F} \\
V_{g} & =26.8 \mathrm{ft}^{3} / 1 \mathrm{bm}=1672 \mathrm{~mL} / \mathrm{g} \\
H_{g} & =1153.5 \mathrm{Btu} / 1 \mathrm{bm}=2.54 \mathrm{Btu} / \mathrm{g} \\
V_{L} & =0.0167 \mathrm{ft}^{3} / 1 \mathrm{bm}=1.042 \mathrm{~mL} / \mathrm{g} \\
H_{L} & =180.17 \mathrm{Btu} / 1 \mathrm{bm}=0.397 \mathrm{Btu} / \mathrm{g}
\end{aligned}
$$

If $x$ is the mass of vapor, the $350-x$ is the remaining liquid mass and an energy balance can be used to determine $x$.

$$
\begin{aligned}
& x(2.54 \mathrm{Btu} / \mathrm{g})+(350-x)(0.397 \mathrm{Btu} / \mathrm{g})=230 \mathrm{Btu} \\
& x=\frac{230-350(.397)}{2.54-0.397}=42.5-\mathrm{g} \text { vapor }
\end{aligned}
$$




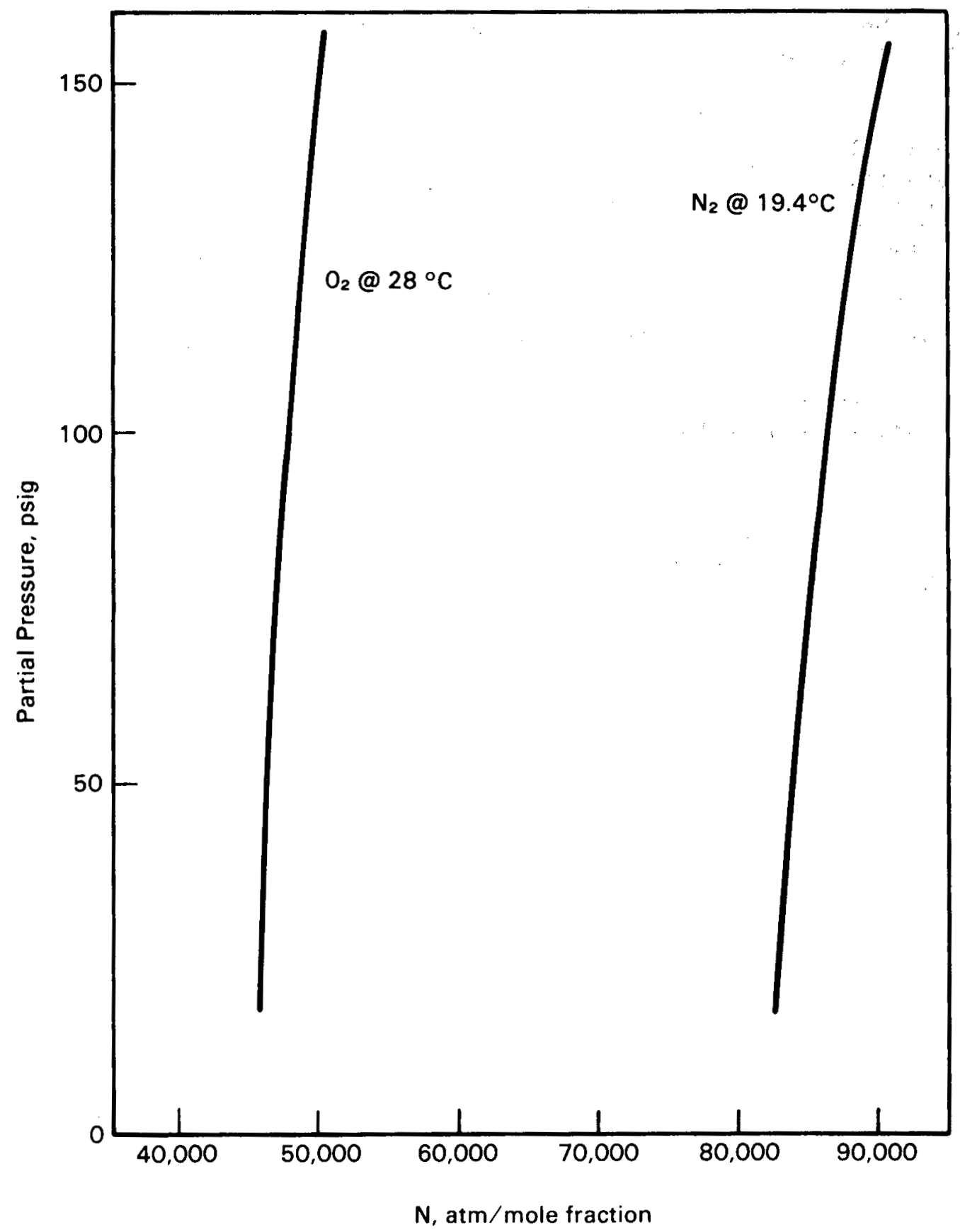

FIGURE B.4. Plot of Henry's Constant, H, Versus Partial Pressure of Oxygen and Nitrogen 
TABLE B.4. Mole Fraction of Air Dissolved in Uranine for Air-Pressurized Releases

\begin{tabular}{|c|c|c|c|c|c|}
\hline \multirow{2}{*}{$\begin{array}{c}\text { Experimental } \\
\text { Pressure, } \\
\text { psig } \\
\end{array}$} & \multicolumn{2}{|c|}{$\begin{array}{l}\text { Partial } \\
\text { Pressure }\end{array}$} & \multirow{2}{*}{ Atm/Mols } & & \multirow[b]{2}{*}{$\begin{array}{l}\text { Mole Fraction } \\
\text { Air in } \mathrm{H}_{2} \mathrm{O} \\
\end{array}$} \\
\hline & $\begin{array}{c}\mathrm{O}_{2} \\
\text { psig }\end{array}$ & $\begin{array}{c}\mathrm{N}_{2} \\
\text { psig }\end{array}$ & & $\frac{\text { e Fraction }}{\frac{\mathrm{N}_{2}}{}}$ & \\
\hline 50 & 11 & 39 & 45,800 & 83,200 & $4.8 \times 10^{-5}$ \\
\hline 250 & 53 & 198 & 46,000 & $95,700^{(a)}$ & $2.2 \times 10^{-4}$ \\
\hline 500 & 105 & 395 & 47,600 & $112,300^{(a)}$ & $3.9 \times 10^{-4}$ \\
\hline
\end{tabular}

(a) Extrapolated values.

Because $1.43 \mathrm{~g}$ vapor were present before release, then $42.5-1.43$

$=41.1 \mathrm{~g}$ vapor were flashed during release. The mass fraction of vapor flashed

$=41.1 \mathrm{~g} / 348.5 \mathrm{~g}=0.12$. 
APPENDIX B REFERENCES

Hougen, 0. A., K. M. Watson and R. A. Ragatz. 1958. Chemical Process Principals. Ind ed. John Wiley and Sons, New York.

Longe, N. A., and G. M. Forker. 1944. Handbook of Chemistry. Fth ed. Handbook Publishers, Inc., Sandusky, Ohio.

Perry, R. H., C. H. Chiton and S. D. Kirkpatrick. 1963. Perry's Chemical Engineers' Handbook. 4th ed. McGraw-Hill Book Company, New York.

B.10 


\section{DISTRIBUTION}

No. of

Copies

OFFSI TE

J. E. Ayer

U.S. Nuclear Regulatory Commission

Office of Nuclear Material

Safety and Safeguard, Division of Fuel Cycle and Material Safety

Advanced Fuel and Spent Fuel

Licensing Branch

Mail St op 55-396

Washington, DC 80555

L. C. Rouse

U.S. Nuclear Regulatory

Commission

Office of Nuclear Material Safety and Safeguard, Division of Fuel Cycle and Material Safety

Advanced Fuel and Spent Fuel Licensing Branch

Mail Stop 55-396

Washington, DC 80555

A. T. Clark

U.S. Nuclear Regulatory Commission

Office of Nuclear Material Safety and Safeguard, Division of Fuel Cycle and Material Safety

Advanced Fuel and Spent Fuel Licensing Branch

Mail Stop 55-396

Washington, DC 80555
No. of

Copies

P. Loysen

U.S. Nuclear Regulatory

Commission

Office of Nuclear Material

Safety and Safeguard, Divi-

sion of Fuel Cycle and

Material Safety

Advanced Fuel and Spent Fuel

Licensing Branch

Mail Stop 55-396

Washington, DC 80555

U.S. Nuclear Regulatory

Commission

Office of Nuclear Reactor

Regulation

Division of Systems Integration

Accident Evaluation Branch

Mail Stop P-802

Washington, DC 20555

W. S. Gregory

Los Alamos National Laboratory

P.0. Box 1663

Los Alamos, NM 87545

B. D. Nichols

Los Alamos National Laboratory

P.0. Box 1663

Los Alamos, NM 87545

W. R. Williams

Martin Marietta Energy Systems, Inc.

Oak Ridge National Laboratory

Process Engineering

P.0. Box $X$

Oak Ridge, TN 37831 
No. of

Copies

\section{ONSITE}

36 Pacific Northwest Laboratory

M. Y. Ballinger (10)

D. W. Dragnich

C. E. Elderkin

J. J. Fuquay

J. M. Hales
No. of

Copies

P. C. Hays

W. H. Hodgson (2)

N. S. Laulainen

J. Mishima

P. C. Owczarski (5)

J. A. Stottl emyre

M. E. Strong

S. L. Sutter

R. E. Wildung

R. K. Woodruff

Publishing Coordination (2)

Technical Report Files (5) 


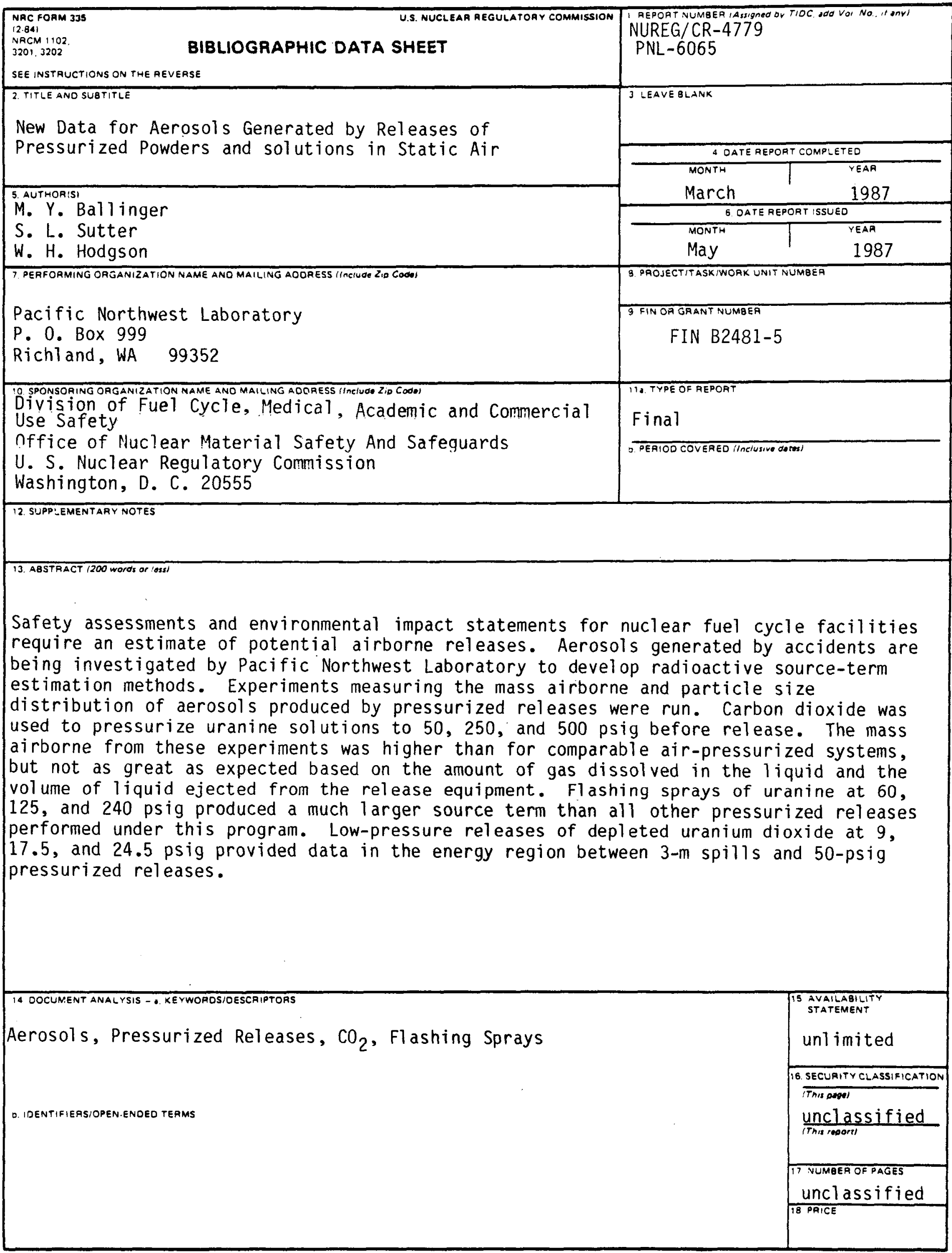

